\title{
Tropical and Subtropical Fruits
}

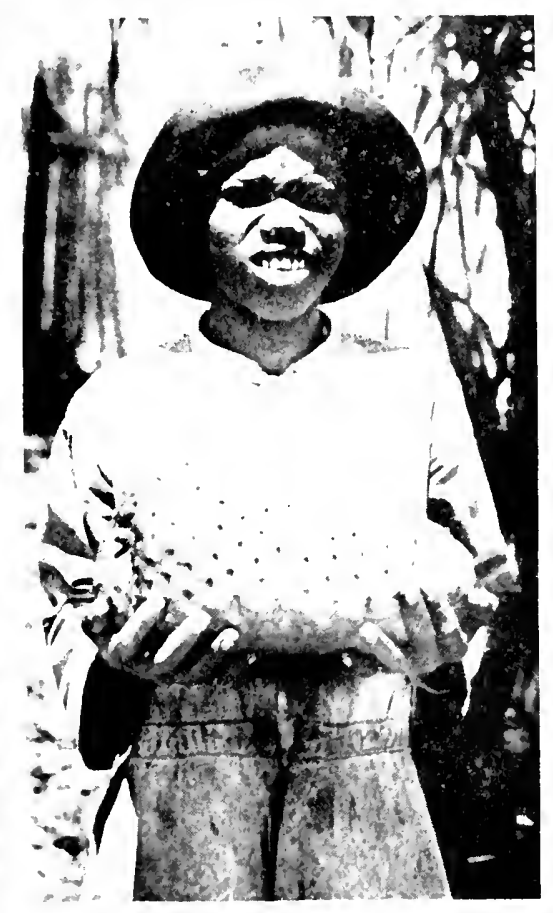

CHICAGO NATURAL HISTORY MUSEUM 
The Popular Series of publications of the Department of Botany is designed to give brief, non-technical accounts of various features of plant life, especially with reference to the botanical exhibits of Chicago Natural History Museum, and of the local flora of the Chicago region.

\section{BOTANICAL PUBLICATIONS, POPULAR SERIES, ISSUED TO DATE}

No. 1. Figs . . . . . . . . . . . . . $\$ .10$

No. 2. The Coco Palm . . . . . . . . . . . . 10

No. 3. Wheat . . . . . . . . . . . . . .

No. 4. Cacao . . . . . . . . . . . . . . . .

No. 5. A Fossil Flower . . . . . . . . . . . . . . $\quad .10$

No. 6. The Cannon-ball Tree . . . . . . . . . . $\quad .10$

No. 7. Spring Wild Flowers . . . . . . . . . . . . $\quad .25$

No. 8. Spring and Early Summer Wild Flowers . . . $\quad .25$

No. 9. Summer Wild Flowers . . . . . . . . . . . $\quad .25$

No. 10. Autumn Flowers and Fruits . . . . . . . . $\quad .25$

No. 11. Common Trees (second edition) . . . . . . . $\quad .25$

No. 12. Poison Ivy (second edition) . . . . . . . . . $\quad .15$

No. 13. Sugar and Sugar-making . . . . . . . . . $\quad .25$

No. 14. Indian Corn . . . . . . . . . . . . . . $\quad .25$

No. 15. Spices and Condiments (second edition) . . . $\quad .25$

No. 16. Fifty Common Plant Galls of the Chicago Area $\quad .25$

No. 17. Common Weeds . . . . . . . . . .25

No. 18. Common Mushrooms ... . . . . . . . $\quad .50$

No. 19. Old-Fashioned Garden Flowers . . . . . . . $\quad .25$

No. 20. House Plants . . . . . . . . . . . . . . $\quad .35$

No. 21. Tea . . . . . . . . . . . . . . . 25

No. 22. Coffee . . . . . . . . . . . . $\quad .25$

No. 23. Carnivorous Plants and "The Man-Eating ${ }^{\text {Tree" }}$

No. 24. Mistletoe and Holly . . . . . . . . . . 25

No. 25. The Story of Food Plants . . . . . . . . . $\quad .25$

No. 26. Tropical and Subtropical Fruits . . . . . . $\quad .50$

CLIFFORD C. GREGG, DiRector

CHICAGO NATURAL HISTORY MUSEUM

CHICAGO, U.S.A. 


$$
\text { . }
$$




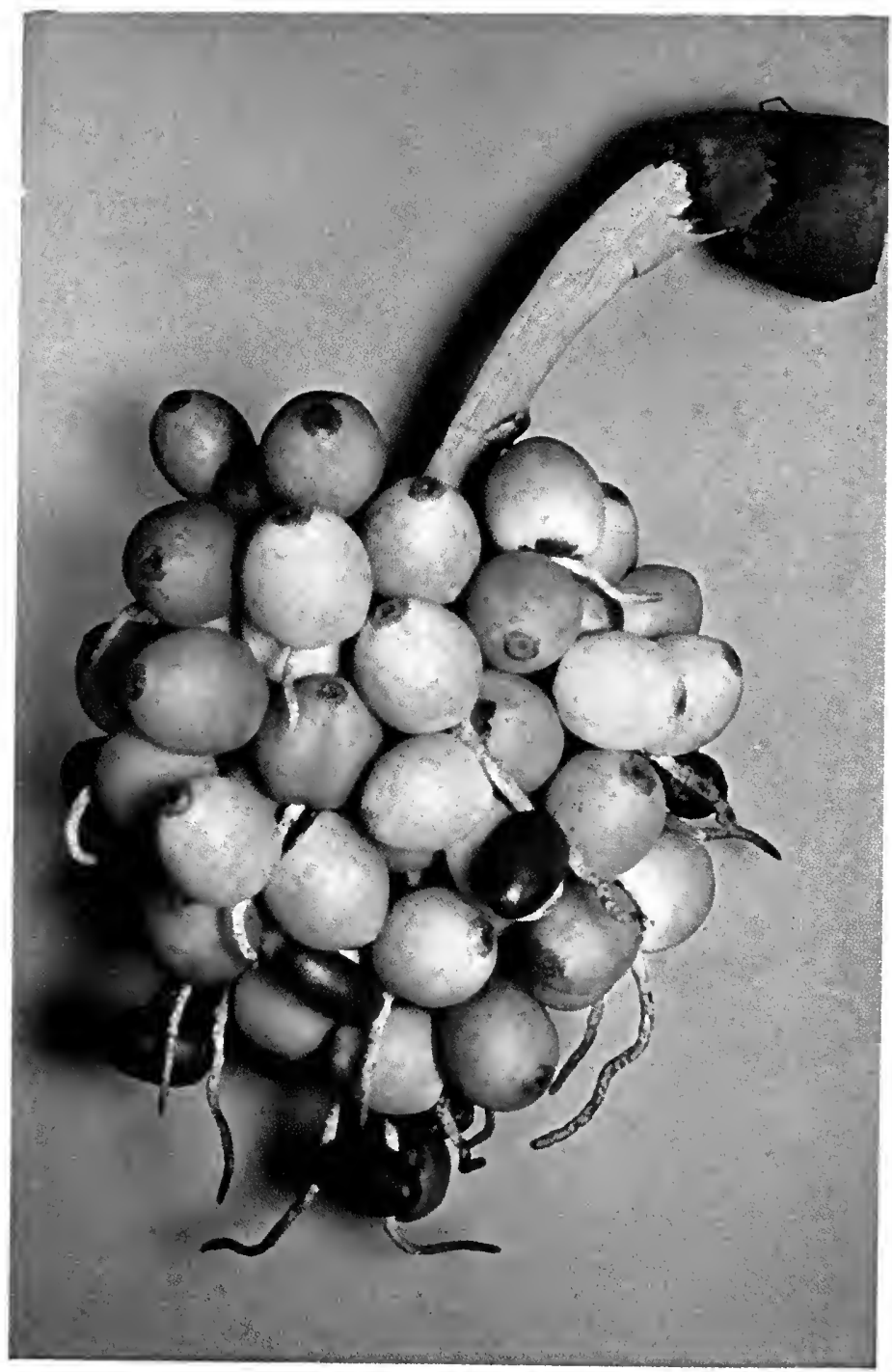

PEACH PALM FRUIT 


\title{
Tropical and Subtropical Fruits
}

BY

\author{
B. E. DAHLGREN \\ CURATOR EMERITUS, DEPARTMENT OF BOTANY
}

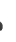

Drawings by Albert FreY

CHICAGO NATURAL HISTORY MUSEUM POPULAR SERIES

BOTANY, NUMBER 26

1947

123995 
PRINTED IN THE UNITED STATES OF AMERICA BY CHICAGO NATURAL HISTORY MUSEUM PRESS

Copyright 1947 by Chicago Natural History Museum 


\section{CONTENTS}

PAGE

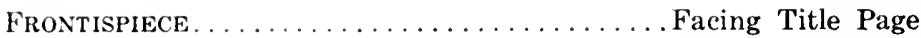
INTRODUCTION .......................

Old World Fruits . . . . . . . . . . . . . . . . . . . 1-28

New World Fruits. . . . . . . . . . . . . . . . . . . 31-67

BIBLIOGRAPHY . . . . . . . . . . . . . . . . . . . . .68-70

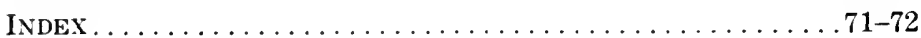





\section{INTRODUCTION}

The larger cultivated fruits of the northern temperate zone, apples, pears, quinces, plums, peaches and their allies, are all of Old World origin, natives of Asia or of Europe where they were thoroughly established long before their introduction into North America. The same is true of most of the smaller fruits. Though some of them are represented in the American flora by identical or corresponding species, it is with few notable exceptions the Old World stock that has been propagated and now yields the bulk of our standard cultivated fruits in their many varieties.

None of them are included in the present publication, which deals with the principal edible fruits of the tropics and of the bordering regions intermediate between the tropical and temperate zones. A large part of these fruits also are of Old World origin. Among their number are some that are native in or about the eastern Mediterranean or have been cultivated there since early historic time or before. Such are the fig, the date, the pomegranate, the common spiny jujube, and perhaps also the lime, identified from seeds that were found in Sumerian excavations in Mesopotamia and indicate its early presence there. Scårcely known in northern Europe and not capable of being cultivated there, these did not reach North America by the northern route, but at an early date directly by way of the Spanish peninsula, together with the oranges, lemons and limes that had been brought to the Mediterranean by Arab traders and become well established there before the time of the great navigators.

The interesting history of the introduction of some of the citrus fruits is summarized in a recent publication by Webber and Batchelor (see p. 70). Columbus on his second voyage brought plants and seeds as well as useful 
animals from Spain and the Canary Islands to the New World. Included among them were the then recently arrived sweet orange for which people of wealth were building orangeries in southern Europe, the sour orange which had been grown in Italy and Spain for several hundred years, the lemon, citron, and lime, as well as melons, figs and pomegranates, all of which were planted and tended in the settlement which Columbus established in the island of Hispaniola, now occupied by the republics of Haiti and Santo Domingo.

From there these fruits soon reached other islands of the larger Antilles and were also carried by Spanish explorers, settlers and missionaries to Mexico, Central America, and Panama, as well as to northern and northwestern South America. The eastern part of the South American continent, which is now Brazil, was supplied by the Portuguese who, after taking possession, promptly introduced seeds and plants from many distinct parts of the world that they were the first to reach.

The east coast of the North American mainland was visited early in the 16th century by Spaniards from the islands who called the southern peninsula Florida and planted citrus and other fruits that flourished and multiplied long after the Spanish settlements had been abandoned. Two hundred years later Bartram in his travels described wild or abandoned groves of such trees on St. John's River (1774). While these consisted mostly of Seville or sour orange, there were also trees of sweet orange, limes and rough lemon growing among the native bay trees, live oaks, and magnolias. Traces of such ancient plantings were once numerous. Their descendants may be seen today in occasional wild sour orange and rough lemon trees in Florida hammocks. Many of these have furnished stock used in the establishment of citrus groves which have multiplied since the peninsula became part of the United States in 1821. The grapefruit, which is considered to have originated from the pummelo brought from the East Indies to Barbados by a Captain 
Shaddock, was first planted in Florida by a Spanish settler in 1809.

On the west coast Spanish missionaries arriving by way of Mexico planted citrus and other subtropical fruits in lower and later in southern California. Some of the earliest groves were started with trees obtained directly from the missions. With the influx of settlers after the acquisition of California by the United States in 1848, citrus groves multiplied. Recent large scale development of citrus culture in this country has been made possible chiefly by improved practices and standards, and a constantly expanding market for the fruit.

Of other exotic fruits brought from Mediterranean countries the principal ones were figs and dates. Though introduced repeatedly in various places in the United States, it is only recently that they can be said to have been well established. The first figs grown in California were black mission figs brought by Franciscans from Spain or Portugal. The successful cultivation of the Smyrna fig had to await the introduction of the fig wasp and a proper understanding of the importance of the so-called caprification of the fig, practised for thousands of years in countries of the eastern Mediterranean. An account of the introduction, culture, varieties, and literature of the fig is found in Eisen's treatise cited in the bibliography (p. 68). The introduction of many kinds of figs from various sources, as well as of many other fruits of foreign countries, is to be credited to many private individuals and growers, as well as to government agencies.

Date palms have been planted in many places in the warmer parts of this country but the successful production of dates in the southwestern states is a recent achievement following the studies of their culture and pollination, especially in the region about the Persian Gulf, and the introduction of selected varieties by Swingle and associates of the United States Department of Agriculture.

Like the peach among temperate fruits, that came originally from China by the overland route to Persia 
before it reached Europe and became established there and finally in North America, some of the tropical fruits have had a history of extensive wanderings. The banana, the most important of all tropical fruits, made its first New World appearance in Hispaniola as did the citrus fruits somewhat "earlier. Originally from the tropics of southeastern Asia, it was transported from India to Africa by Arab traders, and in the course of time, from Arabian settlements or trading posts on the east coast of that continent across the width of Africa to Guinea. Its African name banana was doubtless acquired during the traverse. From the Guinea coast it was only a step to the islands off the African continent. From the Canaries it was brought to Santo Domingo in the 16th century by a Spanish priest. From there it soon spread to other West Indian islands and to Central America which has become one of the main banana producing regions of the world. Introductions of bananas directly from the oriental tropics have of course been made since, both by Pacific and Atlantic routes.

English horticulturists have always excelled in growing exotic plants under glass. The most authentic and complete collection of cultivated figs, comprising sixty-six varieties, was obtained from England for introduction in California. Many new plants were first described from such cultivated specimens. The strawberry guava is an interesting instance. It was obtained from an English grower who had received it from China. It was grown under glass and fruited in England, where it was described and named Cattley guava. It is now recognized as a wellknown fruit of eastern Brazil where it is native; but, early carried to Asia by some Portuguese mariner, it now bears the name of the English horticulturist.

Since the establishment of the office of Foreign Seed and Plant Introduction in the Bureau of Plant Industry, many valuable additions have been made to the fruits capable of being grown in the United States, including superior varieties of those already in cultivation. Vol- 
umes of descriptive lists of seeds and plants brought from many parts of the world testify to the activity of the office. Among the most important of its many introductions of edible fruits is that of the avocado in its various forms from the West Indies, Mexico and Central America. The credit for this belongs to David Fairchild, veteran ex-chief of the Office of Plant Introduction, and Wilson Popenoe, botanical explorer. Many types of mangoes, persimmons, jujubes, and numerous other fruits of foreign lands have been introduced, and others are constantly being added to the experiment gardens of the Bureau of Plant Industry from which they are eventually released to plant breeders and nurserymen.

Unfortunately the area within our boundaries suitable for cultivation of plants requiring tropical or near-tropical conditions is very limited. The banana can be seen growing in scattered clumps in many places in Florida, but for an adequate supply of it we shall doubtless continue to depend on its cultivation in West Indian islands and Central American countries where superior conditions exist for its production. The same is true of pineapples and may be expected to apply also to papayas and various other more or less tropical fruits that are likely to be much in demand once they become well enough known and readily obtainable.

Many products of the tropics are already familiar to a considerable part of the American public. With increase in foreign travel they will become more widely known. With airplane transportation of perishable products under way, it may be confidently predicted that tropical flowers and fruits will make their regular appearance in our markets.

In the following pages the fruits are divided into two groups, those of Old World origin and those of the New World; and the most important in each group are placed first. The others are arranged rather with regard to botanical relationship and usual systematic sequence than in order of importance or excellence. Beyond a certain 
point it appears quite impracticable to attempt to classify according to their relative value the many fruits included, for there can be no general agreement about the quality and popularity of many of them. Anyone who has sampled only a poor mango can scarcely imagine that very superior ones exist. One who has tasted only an unripe persimmon would be likely to rate all persimmons very low. A few of the fruits included might be considered fourth class in a well supplied metropolitan market, but have appreciable merit where the choice is more limited. Some might perhaps have been omitted, and others could have been added.

The scientific names-in italics under each illustration in the following pages - are for the most part old and well established. Where recent changes have been made the old names are placed in parentheses below or after the new.

The foreign or vernacular names cited at the end of each description will be of interest to travelers and residents in other countries of this hemisphere.

Almost all of the tropical and subtropical fruits described and illustrated in the following pages are represented in the botanical exhibits of Chicago Natural History Museum.

The illustrations are from pen and ink drawings by Mr. Albert Frey. Some of them have appeared in a manual edited and printed by the Navy Medical Service during the last year of the second world war. The illustration of Barbados cherry on page 46 is adapted from a drawing in DeCandolle Herbarium, Geneva, Switzerland, of a Sessé \& Mociño plate or collection (F. M. neg. 30564). 


\section{TROPICAL AND SUBTROPICAL FRUITS OF OLD WORLD ORIGIN}

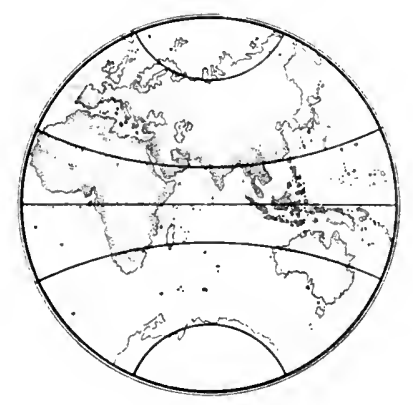




\section{.}




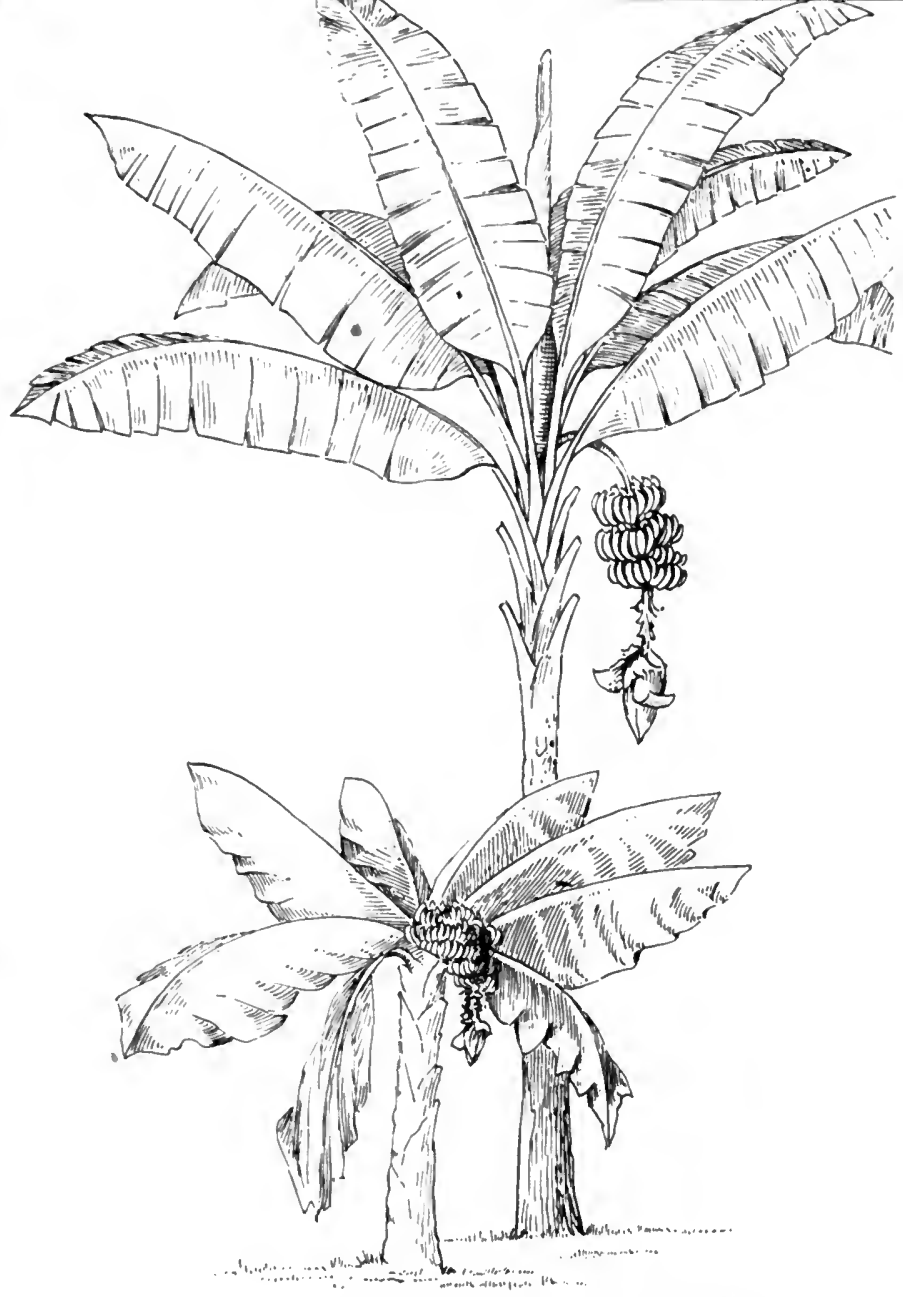

Musa paradisiaca subsp. sapientium

\section{BANANAS}

The cultivated banana is doubtless the most important and most widely grown of all tropical fruits. It is a conspicuous example of a cultivated plant which has definitely lost its ability to produce seed and must be propagated by shoots from its underground stem. It was originally a native of the oriental tropics. There are two main types, the common banana and the dwarf Chinese or Cavendish banana, each with numerous varieties, especially the former. The variety generally grown in Central America and the West Indies for the U.S. market is known as Gros-Michel.

Figue-Banane (Fr.), Banana (Sp. \& P.), Cambur (Venez.), Bacore (Guianas).

The plantain, $M$. paradisiaca, is a more robust plant producing larger fruit which requires cooking.

Pisang (Malay), Meel Banaan (D.), Banane a cuir (Fr.), Plátano (Sp.), Banana da terra, Pacova (Braz.). 



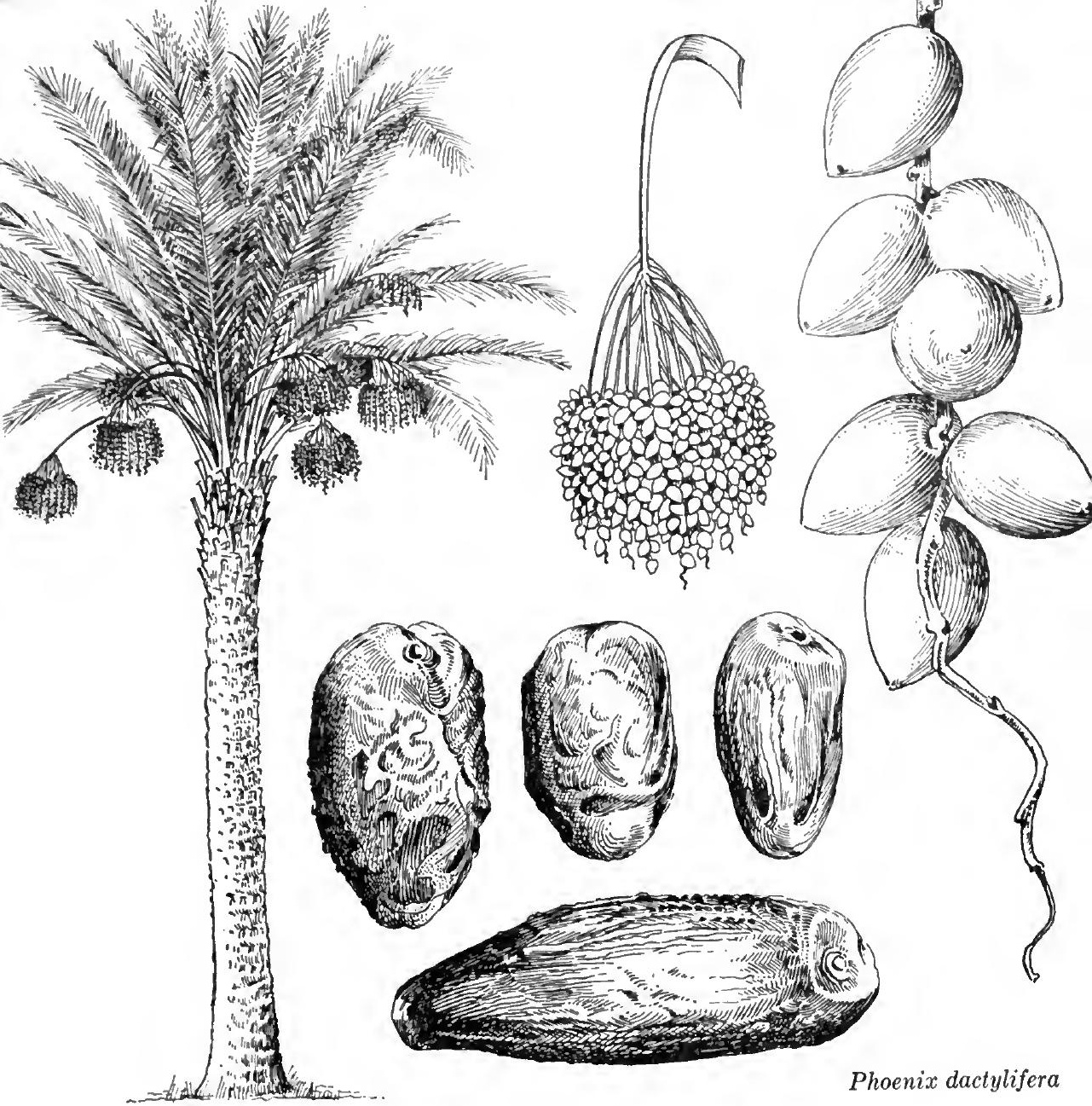

\section{DATES}

Dates are the fruit of a feather-leaved palm of the arid region of southwestern Asia, especially the neighborhood of the Persian Gulf, and westward through Arabia, Egypt, and northern Africa.

There are hundreds of named varieties. Some are strictly local, but a general distinction is made between dry and sweet dates. The former constitute the daily bread of the nomadic Arabs, while softer sweet dates are preferred by other peoples and are packed for export. Some of the best varieties have been introduced into this country and now grow well under irrigation in hot and arid parts of the southwest.

Datte (Fr.), Dátil (Sp.), Tâmara (P.), Dadel (D.). 


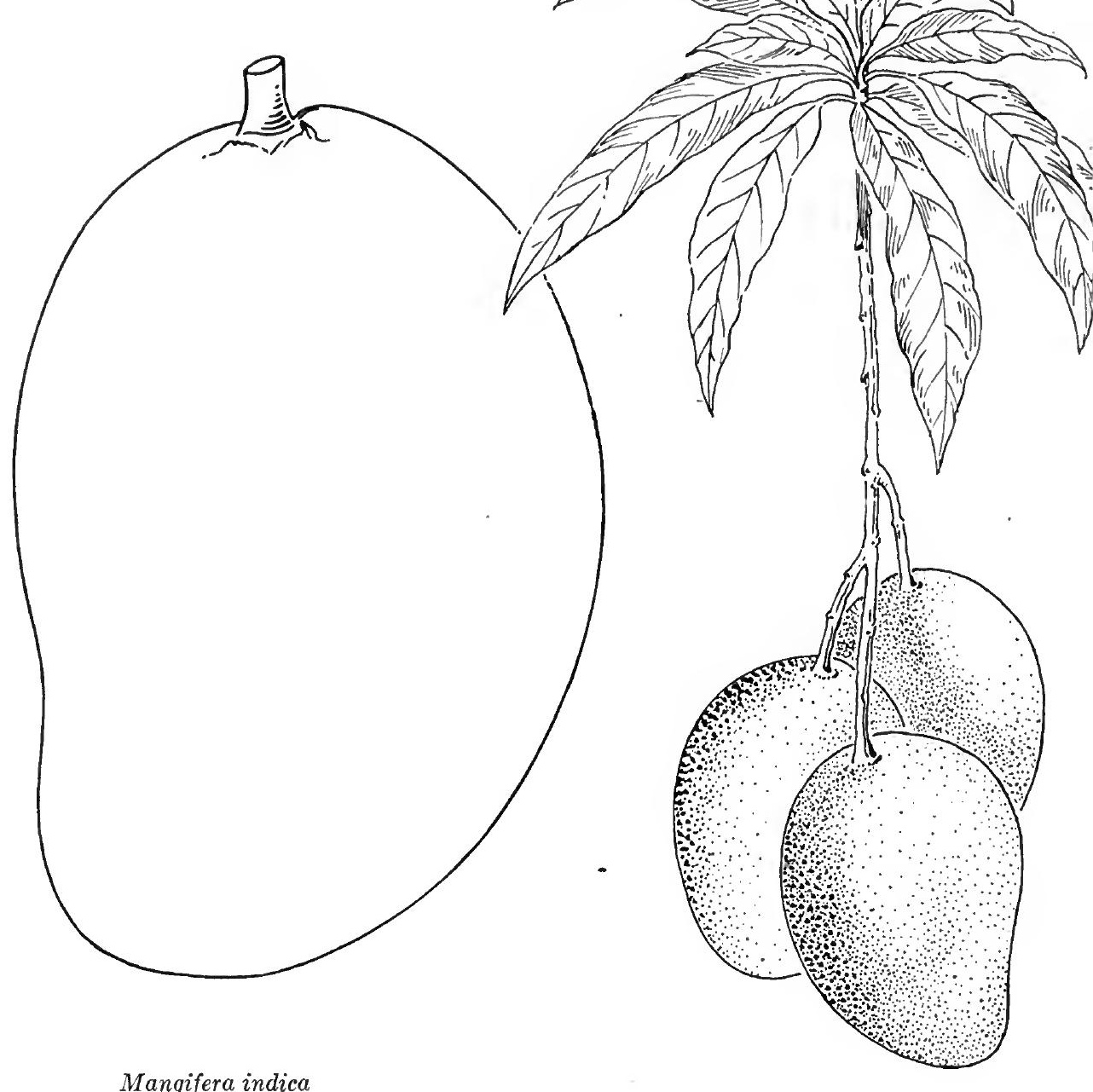

Mangifera indica

\section{MANGO}

A native of India and East Indies, this is the most widely planted of large tropical fruit trees. The numerous varieties now found in all warm countries differ considerably in quality as well as in color, size, and shape of fruit. The soft pulp of the ripe fruit is juicy, sweet, and aromatic, usually with a more or less distinct suggestion of turpentine-like flavor. A mass of fine fibers connects the pulp firmly to the large, hard pit; but the fruit is readily eaten out of hand after slitting the thick skin at the apex and peeling it back toward the base. Usually eaten fresh, it is also made into jam, or cooked with spices and pickled while green as in mango chutney. Sumac family.

Manja (D.G.), Mangue (F.G.), Manga (P.), Mango, Manga (Sp.). 


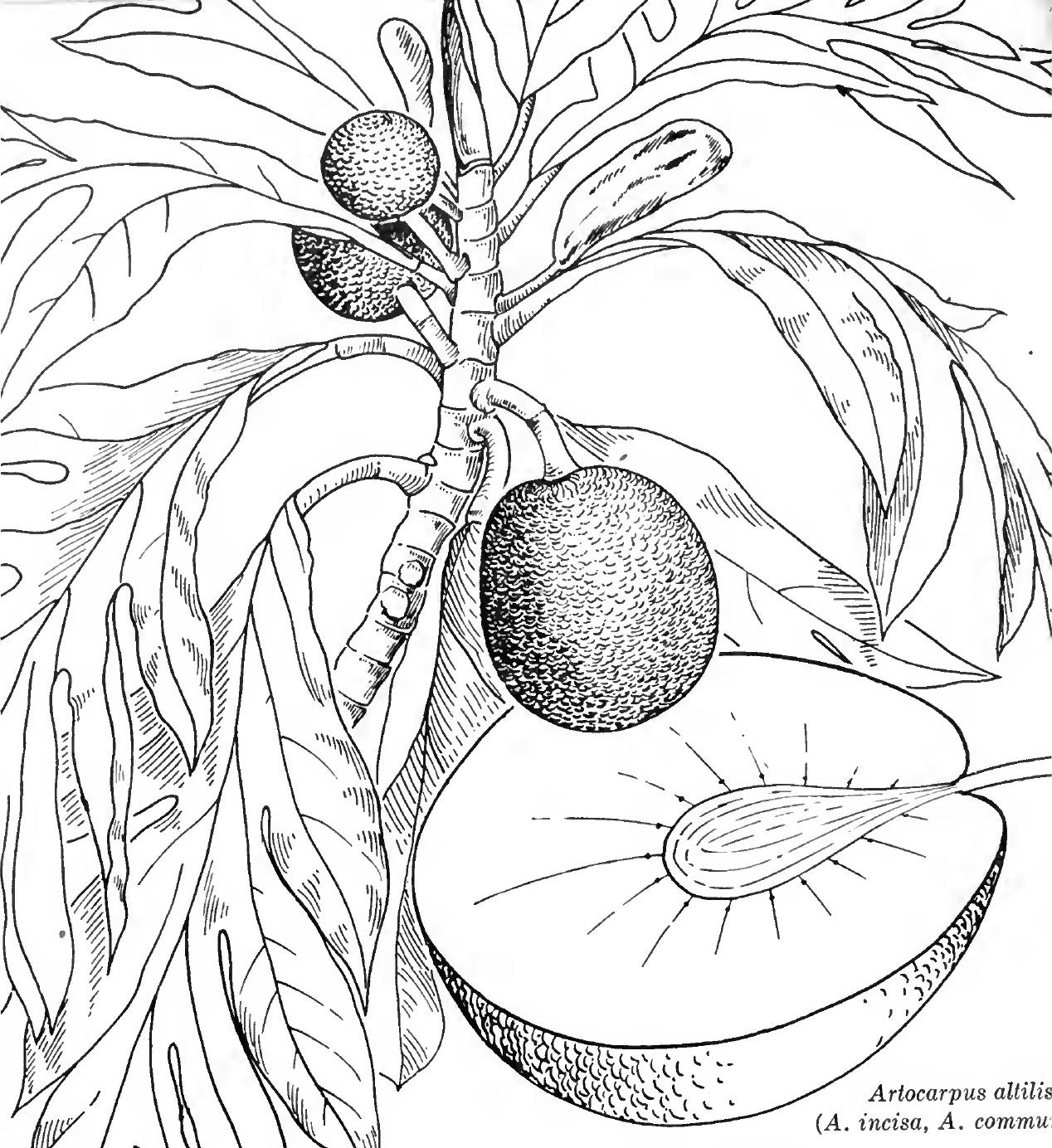

\section{BREADFRUIT}

Breadfruit trees were introduced into the American tropics from the Pacific islands. There are two kinds, those having fruits with and those without seeds. The fruit of the former is prickly, and only the somewhat immature seeds are eaten, boiled in salt water or roasted like chestnuts. The seedless breadfruit illustrated here is eaten baked, boiled, or sliced and roasted, or even fried. Boiled and mashed it may be prepared and seasoned like macaroni. A part of the dramatic story of the introduction of the tree is familiar to readers of The Mutiny on the Bounty by Nordhoff and Hall. Mulberry family.

Broodvrucht (D.G.), Arbre a pain (F.G.), Fruta de pan, Pan de pobre (Sp.), Fruta pão (Braz.). 


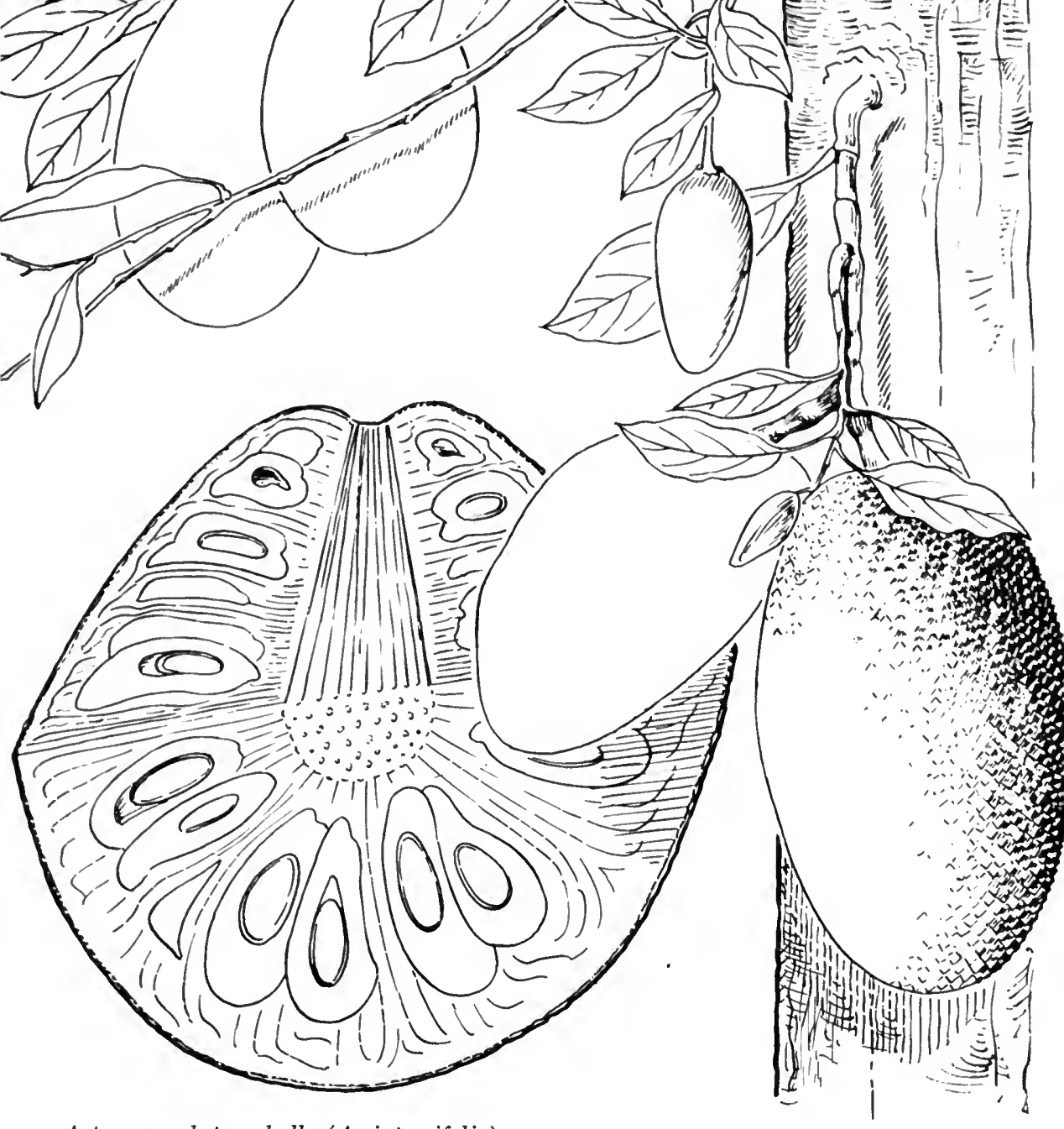

Artocarpus heterophylla (A. integrifolia)

\section{JACKFRUIT}

A large and handsome tree of India, long grown in the Malayan region, the jackfruit was introduced in the American tropics, especially Jamaica and Brazil. It has simple, dark green shiny leaves and rough or prickly compound fruits of the size of watermelons, which grow on short stalks directly from the stem or old branches. The large brown seeds are edible when roasted. The fleshy sweetish yellow pulp about the seeds is boiled, and is esteemed by those who are not deterred by its heavy musky odor. Mulberry family.

Jak from the Portuguese Jaca, "Tsjaka" (Brit. Malaya), Jacca (D.), Jacque (F.), Jaca, Jaca da Baía (Braz.). 





\section{TAMARIND}

This is the fruit of a large leguminous tree of India, now established in all tropical countries. It is recognized by its delicate feathery foliage and curved brown pods which remain hanging for a long time on the tree. The smooth seeds are imbedded in a brown pulp of agreeable sweet-acid flavor and are said to contain more acid and more sugar than any other fruit. The pulp serves for the preparation of a refreshing drink and is used sometimes to add bulk and flavor to guava jelly. Bean family.

Tamarinde (D.G.), Tamarin (F.G.), Tamarindo (Sp.\& P.). 


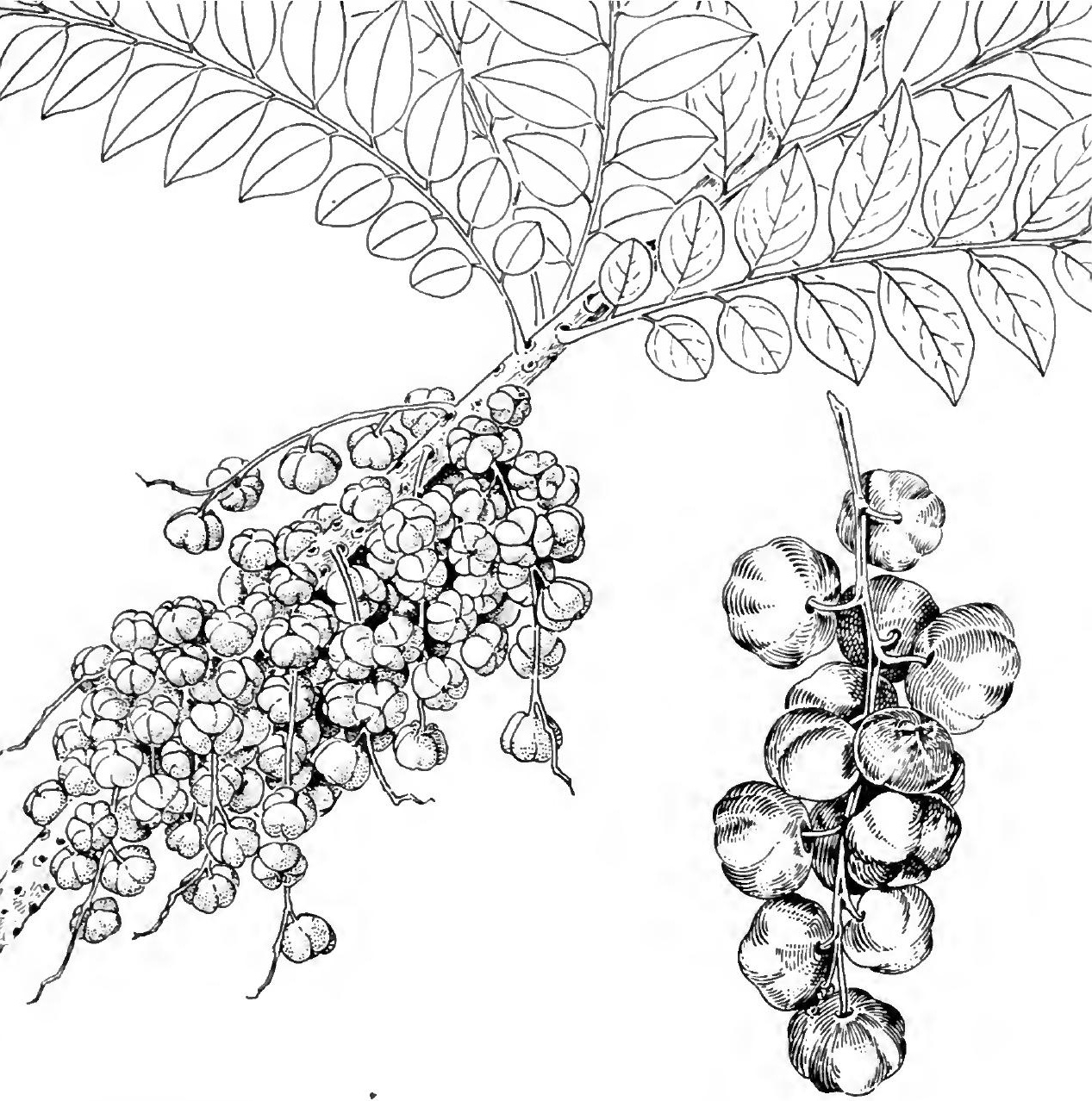

Phyllanthus distichus

(Cicca disticha)

\section{O'TAHEI'TE GOOSEBERRY}

This small tree, introduced from India or the East Indies, with small, apparently pinnate leaves on slender twigs at the tips of the branches, bears an abundance of small fruit in clusters on the stems. The fruits, of the size of cherries, are pale green and smooth but ribbed, yellow when ripe, with crisp flesh and a single seed. Even when fully ripe they are too acid to eat raw but excellent when cooked with sugar. Spurge family.

Otaheite Gooseberry (B.W.I.), Cerise de l'Inde (F.), Cerezo, Cerezo comun, Cerezo agrio, Grosella (Sp.), Groselha (Braz.). 





Blighia sapida

\section{AKEE}

This tree of west African origin is planted in the West Indies and South America for its handsome foliage and showy clusters of peculiar fruit. The latter, about the size of large lemons, turn yellow and bright red as they ripen; at maturity they split lengthwise into three parts and display three large black seeds. Each seed projects from a glistening white, or ivory-colored mass of edible tissue. This "aril" is a good vegetable with a nutty flavor when stewed and browned in butter; but it must be taken at exactly the right stage, since it is poisonous when immature and when over-ripe. The seeds and any pink or purple-tinged parts near the seed should be discarded as dangerous; it is safest to leave the Akee alone. Soapberry family. 


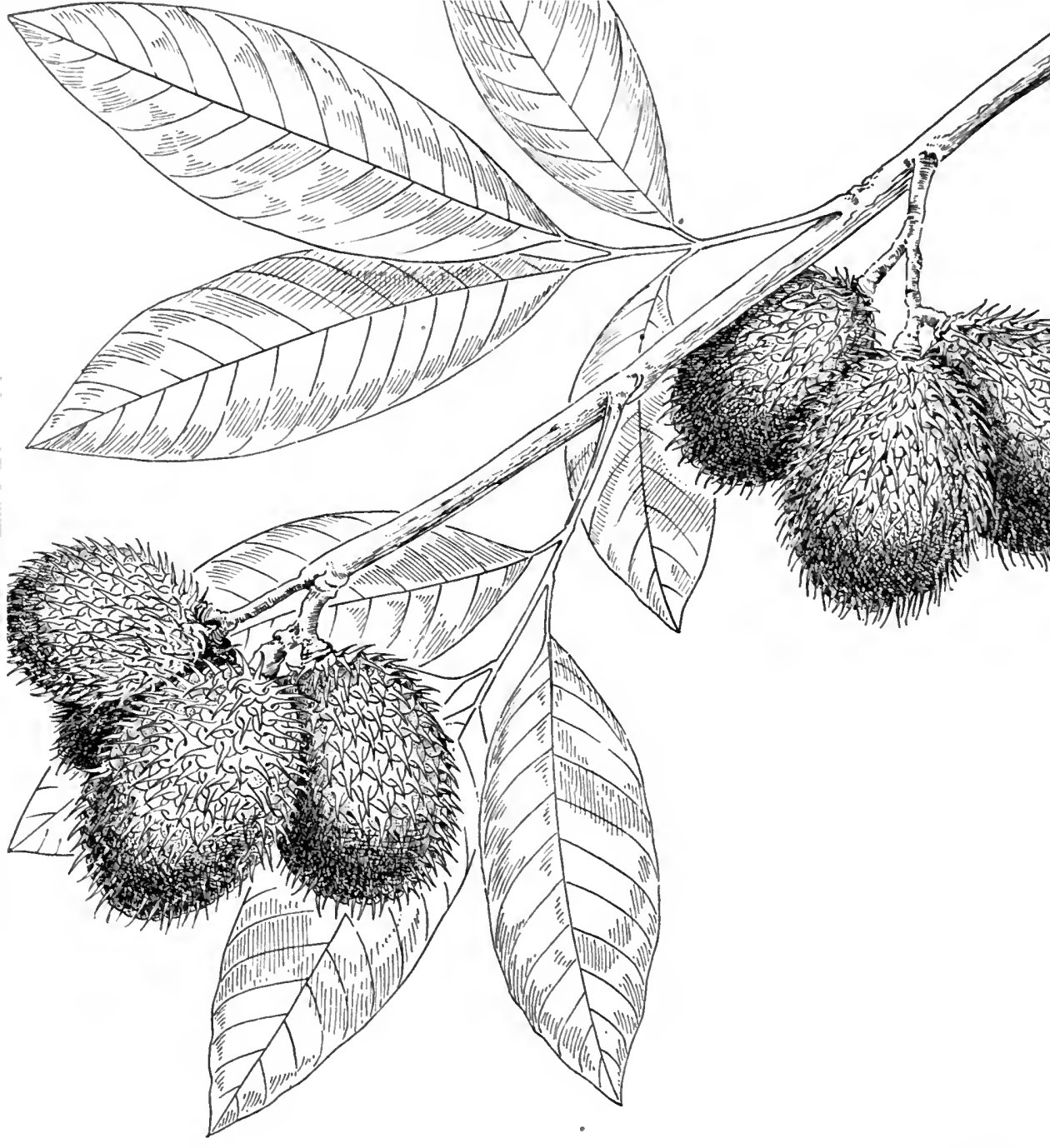

Nephelium lappaceum

\section{RAMBUTAN}

This fruit of tropical Asia, closely related to the Litchi and with the same general characters, is usually much larger with a more brittle rind or shell, beset with long soft spines. The single seed, an inch or more in length, is covered as in the Litchi with a whitish, semi-transparent, juicy pulp, sweet-acid in taste and of very agreeable flavor.

A very similar fruit covered with large blunt-pointed tubercles instead of soft spines is the Malayan Kapulasan or Palasau, called Bulala in the Philippines. Soapberry family. 





Durio zibethinus

\section{DURIAN}

This fruit tree of the Indian archipelago is commonly planted in the East Indies for its large globose pendulous fruits. These weigh from five to six pounds and are famous for their combination of delicious flavor and disagreeable odor of decayed onions. The fruit has a thick fibrous rind beset with coarse pyramidal spines. Internally it is 4-celled, with from two to six large seeds in each division, covered with a whitish, buttery, and aromatic flesh or pulp which is the edible part of the fruit. Silk-cotton family. 




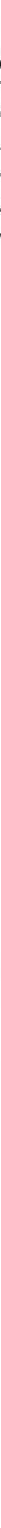

\section{ROSE-APPLE}

A small garden tree introduced from Indo-China or Java and grown for the sake of its rose-flavored fruits, one to two inches in diameter, usually whitish or ivory-colored with crisp thin flesh and generally hollow with a single large spherical seed, or sometimes two or three, within the seed cavity. It may be eaten fresh, and makes a rose-flavored preserve. Myrtle family.

Pommerose (D.), Pomme-rose, Jamrose (Fr.), Pomarosa, Pomarrosa (Sp.), Jambo cheiroso (P.). 


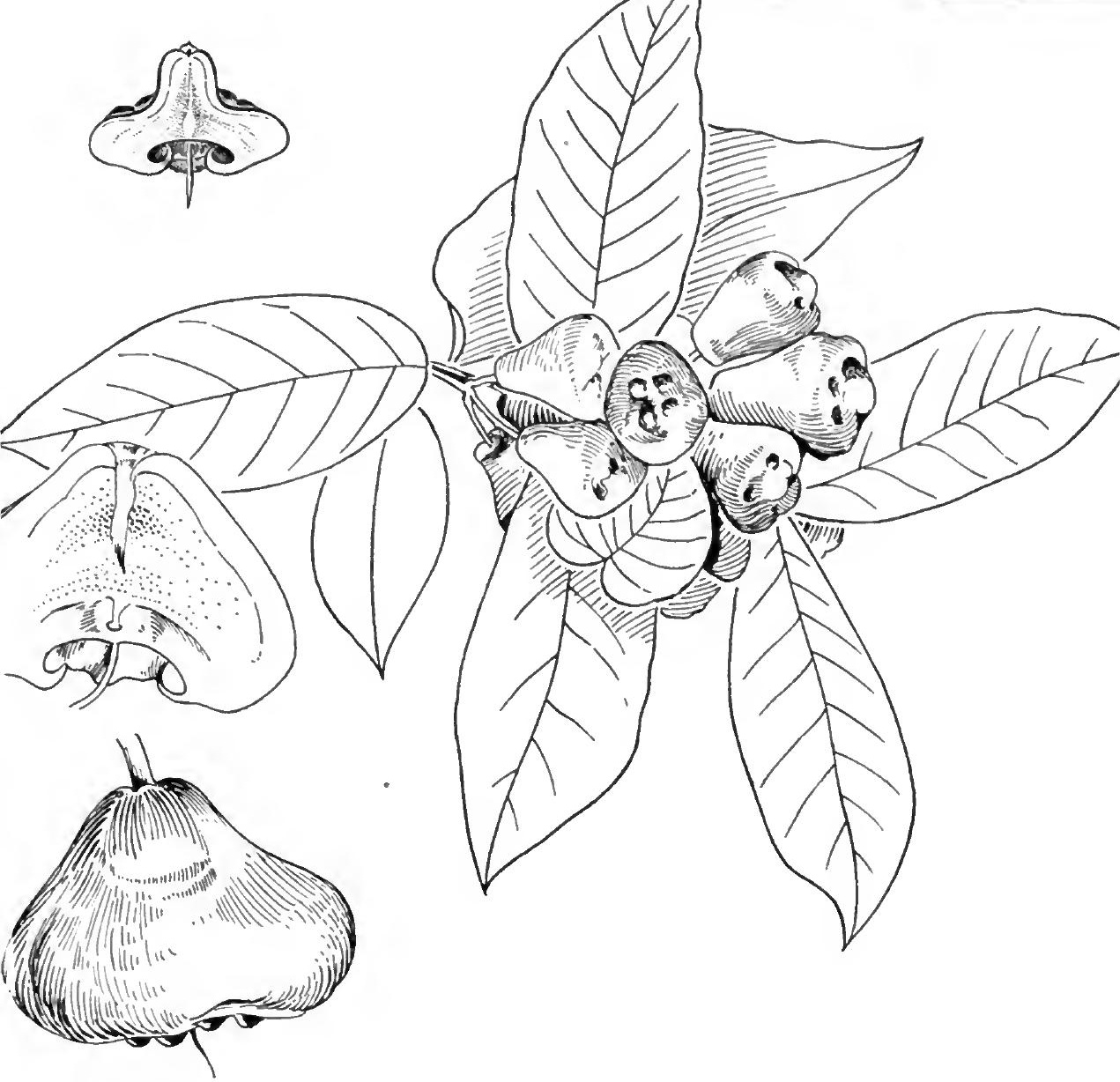

Syzygium javanica (Eugenia javanica)

\section{CURA CAAO-APPLE}

This is a small ornamental Malayan tree producing clusters of pretty rose-pink or purplish-white waxy-looking pear-shaped fruit. The pulp is pleasantly sour-sweet but is usually too fluffy or pithy to be agreeable if eaten fresh. Myrtle family.

Jambosa, Wax jambo (B.E.I.), Macopa (Philipp.).

The Water Rose-apple ( $S$. aquea) is a smaller tree producing similar but smaller fruit, white or pinkish red, easily distinguished from the above by its constricted stem and expanded apex.

Jambo ayer (F.), Pommerak (D.G.). 


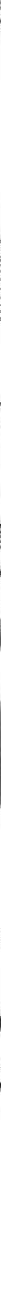

Syzygium Cuminii (Eugenia Cuminii)

\section{JAVA-PLUM}

This is a medium sized to large tree of Java, introduced into many near and remote places, including some in the Western hemisphere. Its plum-like fruits are produced in clusters from the wood of the whitish branches. The fruit is variable in size and shape and ranges in color from a purplish red to deep blackish violet. It has a thin skin, juicy, acid, slightly tinted flesh, enclosing an oblong seed. Superior varieties yield fruit of agreeable flavor. Myrtle family.

Black plum (B.W.I.), Jambolan, Jamelong, Jamblang, etc. 


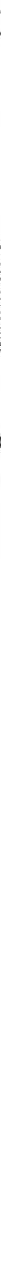

Diospyros Kaki

\section{JAPANESE PERSIMMON}

Closely related to our American wild persimmon, the so-called Japanese persimmon, or Kaki, is a subtropical tree of Chinese origin that has been cultivated for several hundred years in Japan. In the East Indies the fruit is known as Chinese plum; when dried it is called Chinese fig. There are hundreds of varieties, some of which produce seedless fruit. Some of the best varieties have been introduced into the United States where the fruit for the most part is still considered exotic. Until perfectly ripened for some time after picking the persimmon fruit is apt to be very astringent. The black sapote of Mexico is a related species with blackish sweet pulp. The persimmons belong to the Ebony family.

Kaki plum, Kaki fig, Keg fig, Chinese date plum. 
TROPICAL AND SUBTROPICAL FRUITS OF NEW WORLD ORIGIN

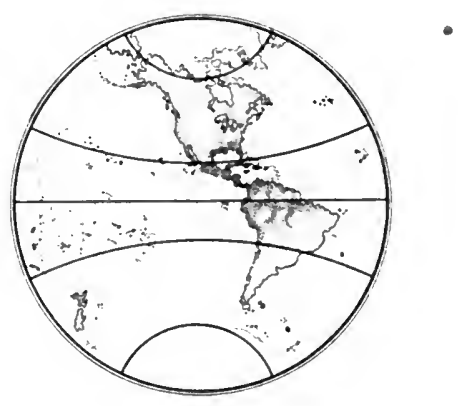








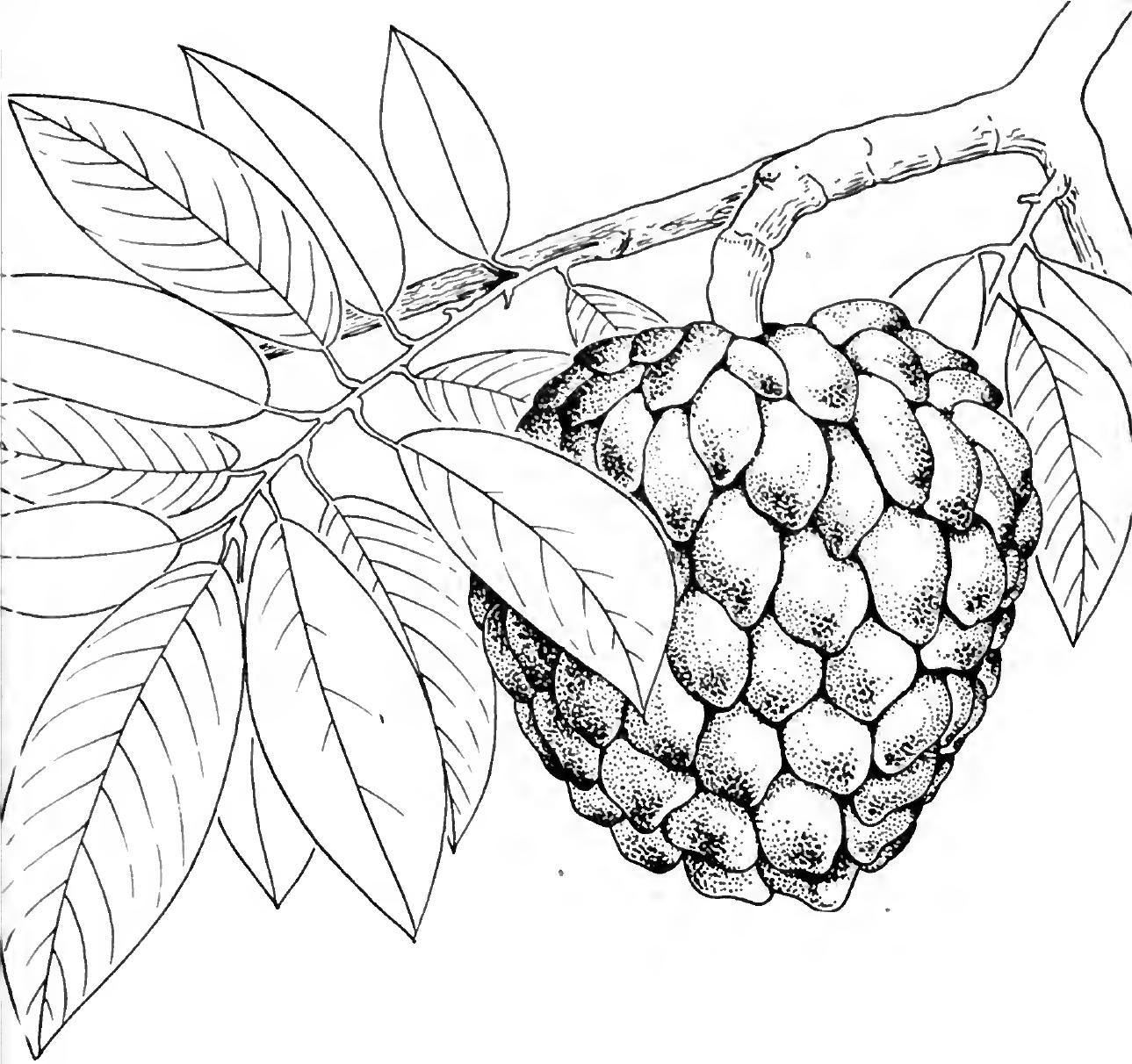

Annona squamosa

\section{SWEETSOP}

This small tree with simple oblong leaves has fruits shaped roughly like large blunt pine-cones with thick, gray-green or yellow scales. The fruit is easily split or broken when ripe, and is seen to have numerous dark brown glossy seeds imbedded in the creamcolored, very sweet pulp. It is always eaten fresh. The tree is native from southern Florida throughout the Caribbean region, and common in northern and eastern South America, also in many places in the Old World tropics where it has been introduced. Annona family.

Sugar-apple (B.W.I.), Kaneelappel, Boe anona (D.), Pomme canelle (Fr.), Anón (Sp.), Ata, Pinha, Fruta de conde (Braz.). 




Annona muricata

\section{SOURSOP}

This large West Indian fruit of characteristic spiny appearance is widely planted in the tropics. It is edible only when thoroughly ripe and the skin begins to blacken. When the large rough fruit, which may attain a weight of 8 to 10 pounds, becomes soft and juicy, it is easily split. The very white, somewhat cottony pulp then is seen to consist of many equal divisions, each with a large brown seed. Transferred to a pitcher the aromatic pulp of a ripe soursop readily parts with its juice, yielding an excellent lemonade-like beverage. Annona family.

Zuurzak (D.), Corossol epinaux (Fr.), Guanábana (Sp.), Graviola, Jaca de Pará (Braz.). 


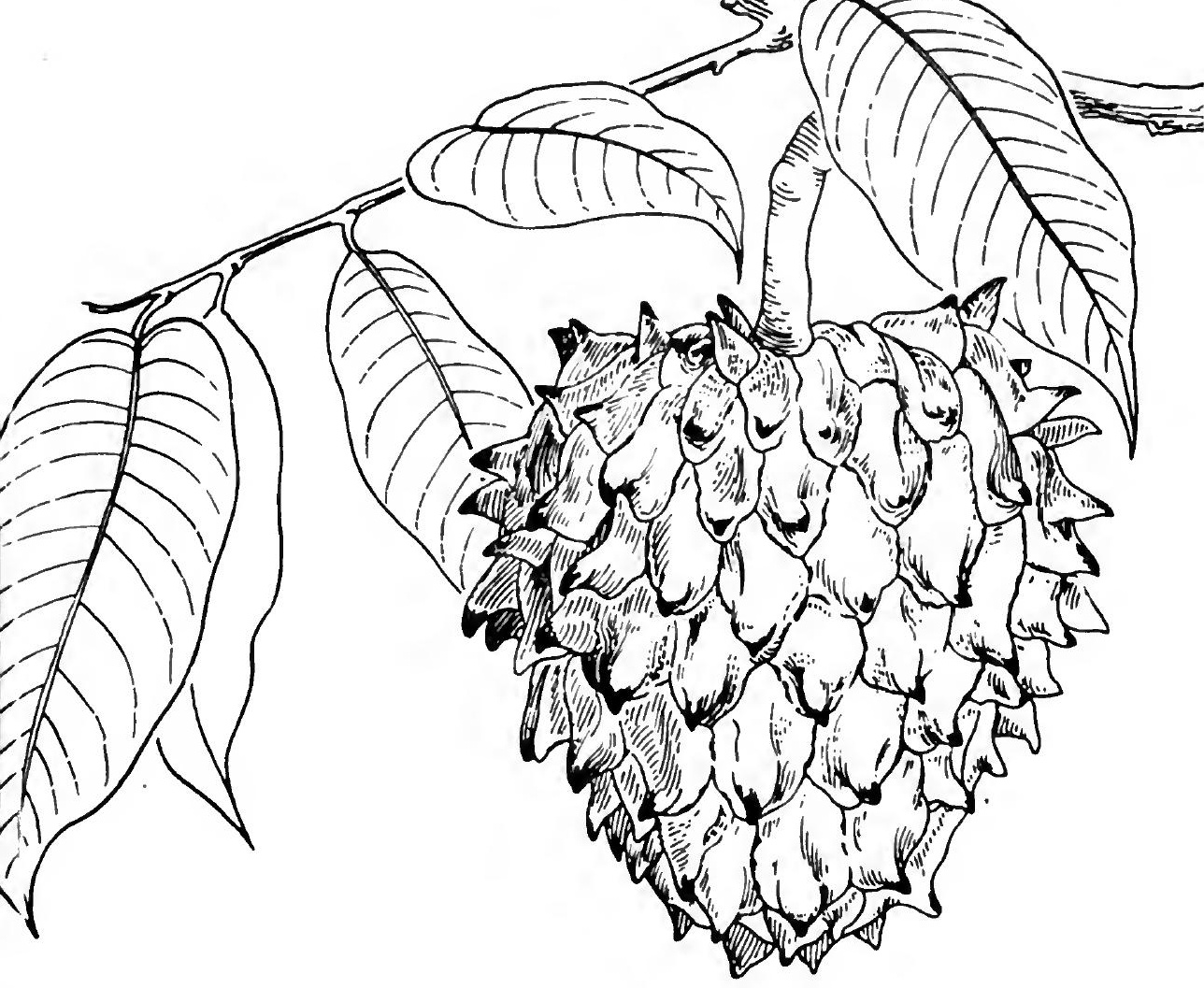

Rollinia pulchrinervia

\section{BIRIBÁ}

This Brazilian fruit is related to the sugar apple and soursop and bears evident resemblance to the latter, but is usually paler green or yellowish and has thicker soft projections. It is produced by a large tree, native of the lower Amazon region, where it is said to have been brought into cultivation by the Indians. It is now widely planted in Brazil and is one of the best among fruits of its kind. There are many related wild fruits in Brazil, some of them more or less edible, generally known as Araticum. Annona family.

Biribá, Fruta de condessa (Braz.). 



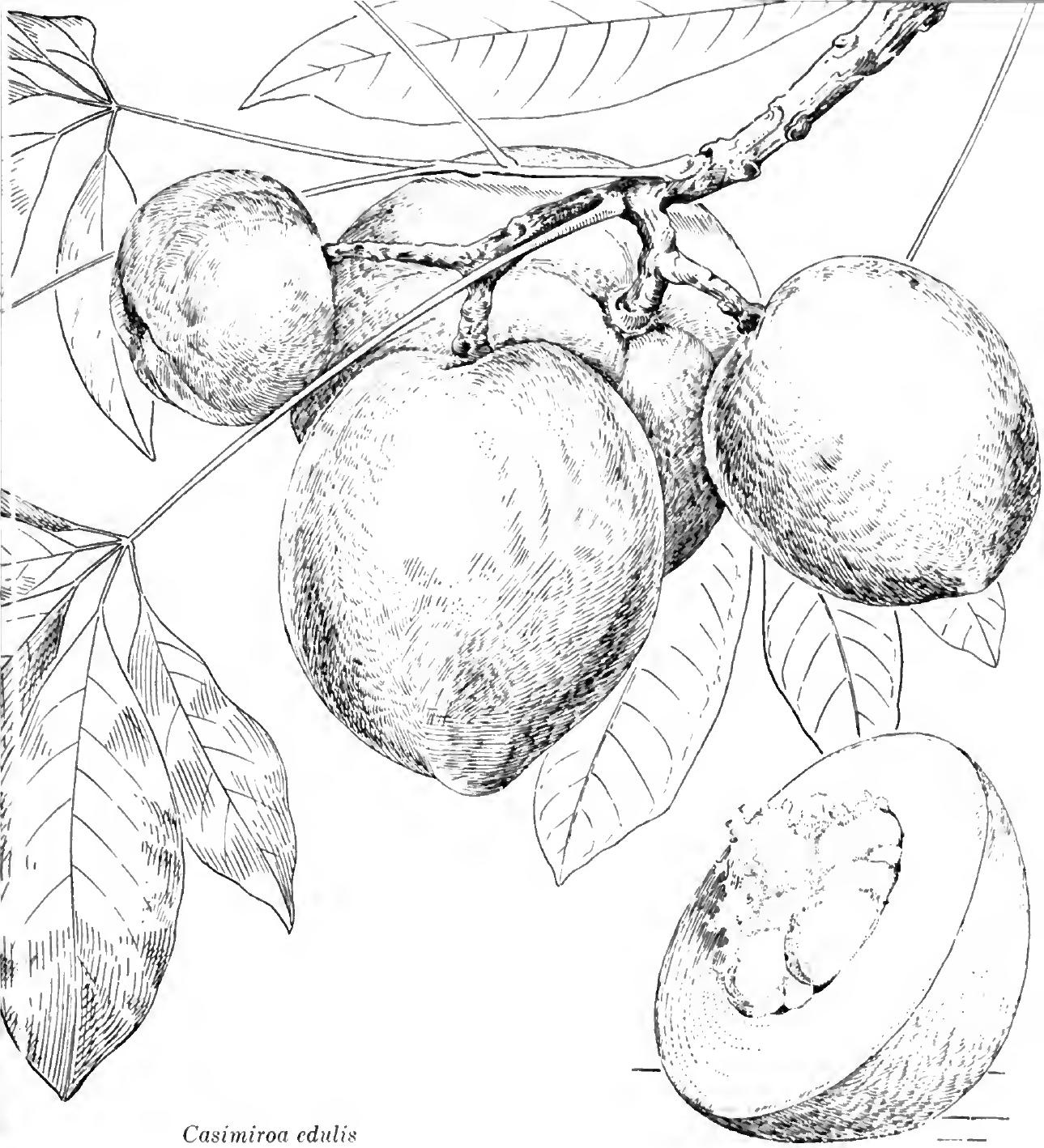

\section{WHITE SAPOTE}

This is the fruit of a medium-sized spreading tree with pale bark and palmate leaves, common in the highlands of Mexico and Central America and planted there and throughout the Caribbean regions. The yellow-green fruit, of about the size of a small orange, has a thin skin, and a bright. yellow soft juicy pulp of pleasant taste, which encloses three to five large seeds. In places the fruit has the reputation of being injurious to health, and it is therefore called matasano. It grows well in southern and middle Florida. Rue family. 


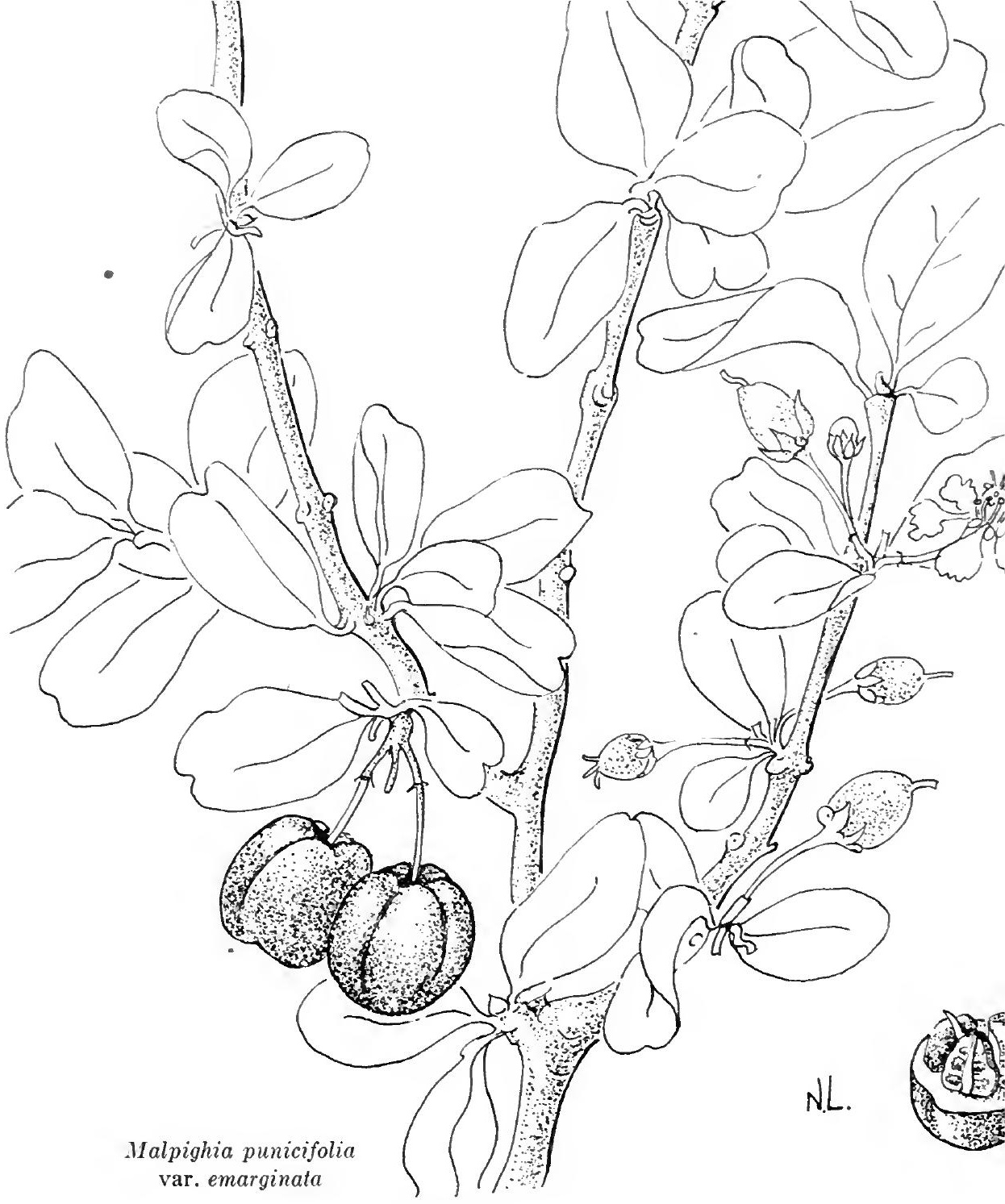

\section{BARBADOS CHERRY}

This is a shrub or small tree with simple thin shiny leaves in pairs and small delicate clusters of white or pinkish flowers. The fruit is cherry-like but three-lobed, with three parchment-like one-seeded pits. It is thin-skinned, juicy and edible, pleasantly aromatic but acid in its natural state but improved by cooking with sugar. It is used also to prepare a lemonade-like drink. Malpighia family.

Geribde kers, Montje-Montje kers, Switie kersie (D.), Cerise des Antilles, Cerise carrée, Lucée (Fr.), Semeruco, Cereza, Cereza de Jamaica (Sp.), Cereja do Pará (Braz.). 



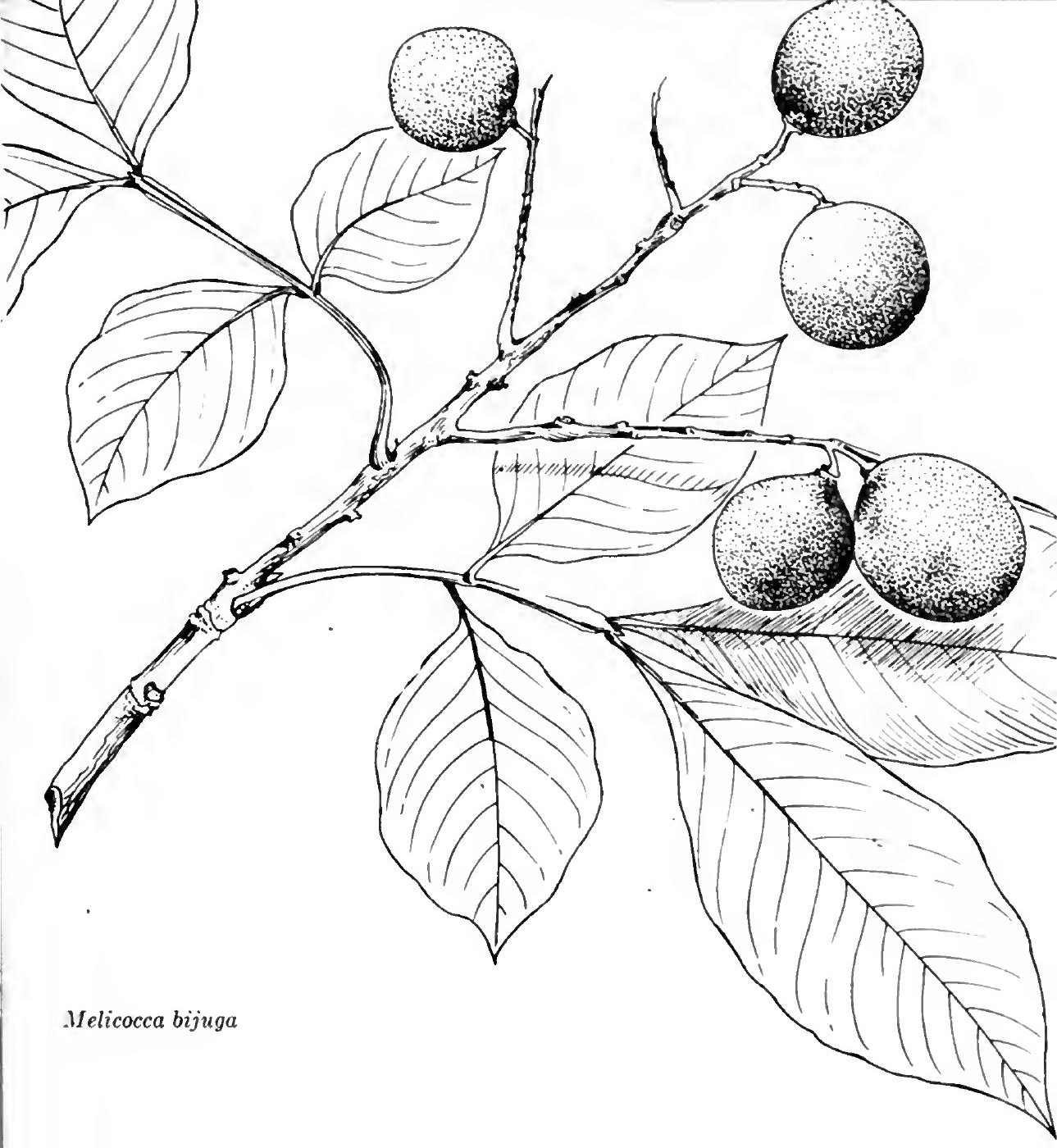

\section{GENIP}

This tall tree, native of northern South America, produces catkins of small greenish flowers and bears fruit the size of plums. The fruits are green with leathery skin. The soft white-yellowish or salmon-colored pulp is gelatinous and pleasantly sweet-acid though somewhat astringent. The large single seeds are edible when roasted like chestnuts. Soapberry family.

Spanish lime (B.W.I.), Honey-berry, Marmalade-box, Maca (B.G.), Knippa, Sensiboom (D.G.), Kenep, Quenett (F.G.), Mamón, Mamoncillo (Venez.). 


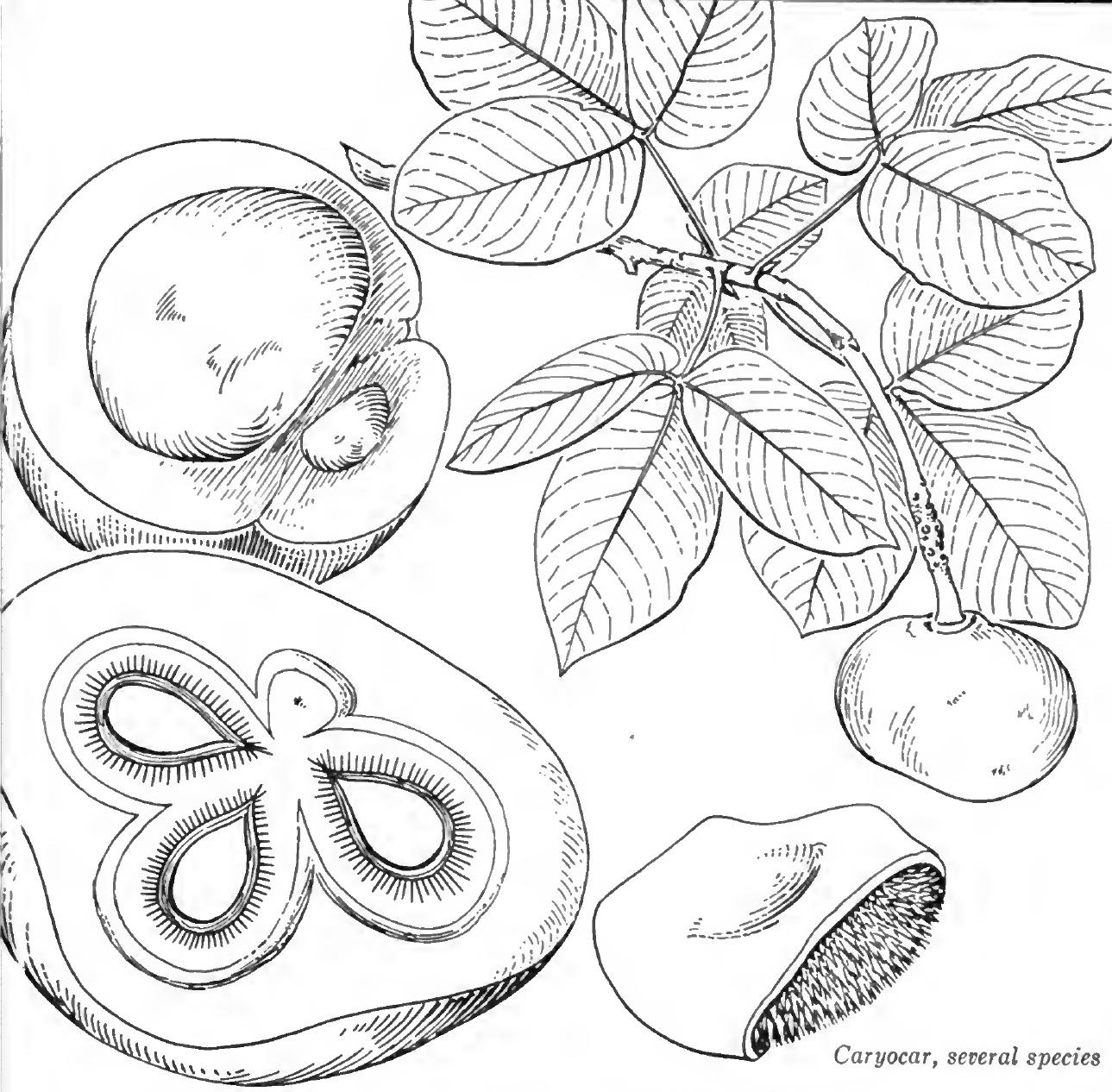

\section{SOUARI NUTS}

These are large forest trees of the humid parts of the Guianas and northern Brazil with characteristic foliage and large globose graygreen fruits each containing one, two, or three large seeds. The yellow flesh is smooth and buttery when cooked; it is eaten as a vegetable for its flavor with fish or meat. The seeds, "butter-nuts," have hard shells. Those of the delicious Souari nut of Guiana are woody and smoothly warty, while those of several Brazilian species (Piquiá) are smooth when unbroken but composed of dangerously sharp spicules which must be avoided with extreme care. Souari-nut family.

Butter-nut, Pekea (B.G.), Butterboom, Sawari root (D.), Arbre a beurre, Chaouari (F.), Piquiá, Amêndoas de Brasil, Amêndoas de Chachapoyas (Braz.). 



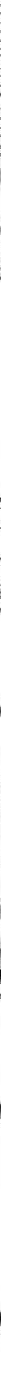

Passiflora quadrangularis

\section{GIANT GRANADILLA}

This large passion-flower vine, native of tropical America, is grown for its ornamental flowers and for its fruit, which is the largest of its genus but of less distinctive flavor than those of smaller species. The word granadilla is of Spanish origin and means "little pomegranate," the name probably having been applied first to one of the smaller species. The resemblance to the pomegranate consists in the numerous seeds, each of which is covered with edible pulp. Passion-flower family.

Groote markoesa (D.G.), Barbadine (Fr.), Granadilla (Sp.), Parcha granadina (Venez.), Maracujá-assú, Maracujá mamão (Braz.). 


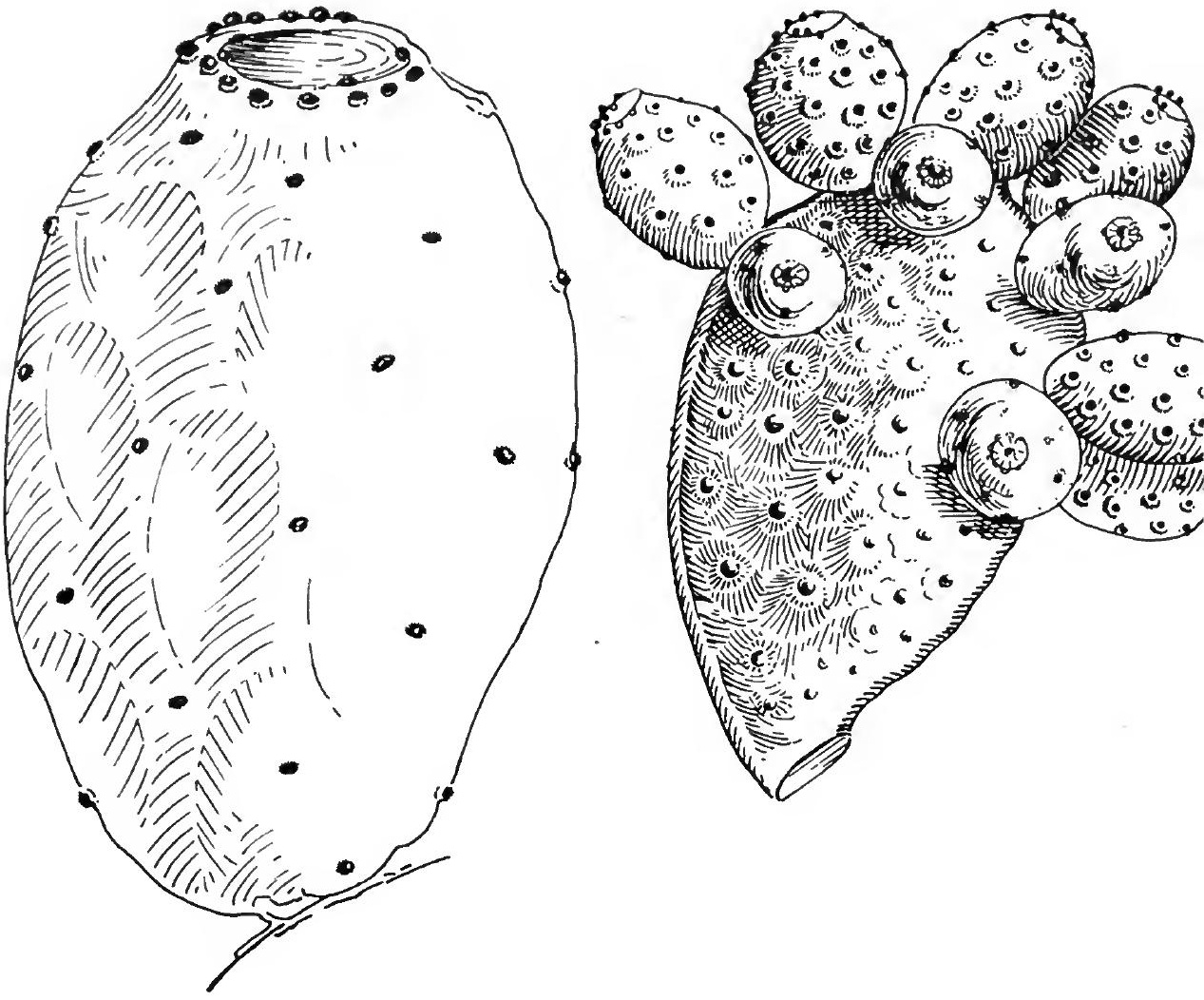

Opuntia Tuna and other species Cereus, several species

\section{TUNA OR PRICKLY PEAR}

The spiny cacti of all types-flat-jointed, climbing, erect and post-like, candelabrum-branched, and tree-like-all produce large attractive flowers which develop edible fruits, generally yellow or red in color and usually conspicuous. They furnish food of agreeable taste but may be dotted with cushions of minute spines which must be thoroughly removed. A superabundance of seeds detracts from the edibility of various species. Cactus family.

Figue d'Inde, Figue de Barbarie (Fr.), Indische vijg, Distelpeer (D.), Cardón, Tuna cardona, Tuna mansa, Pitaya, Duraznillo, Nopal Camuesa (Sp.), Figo da India, Fruta de bôbo (P.). 


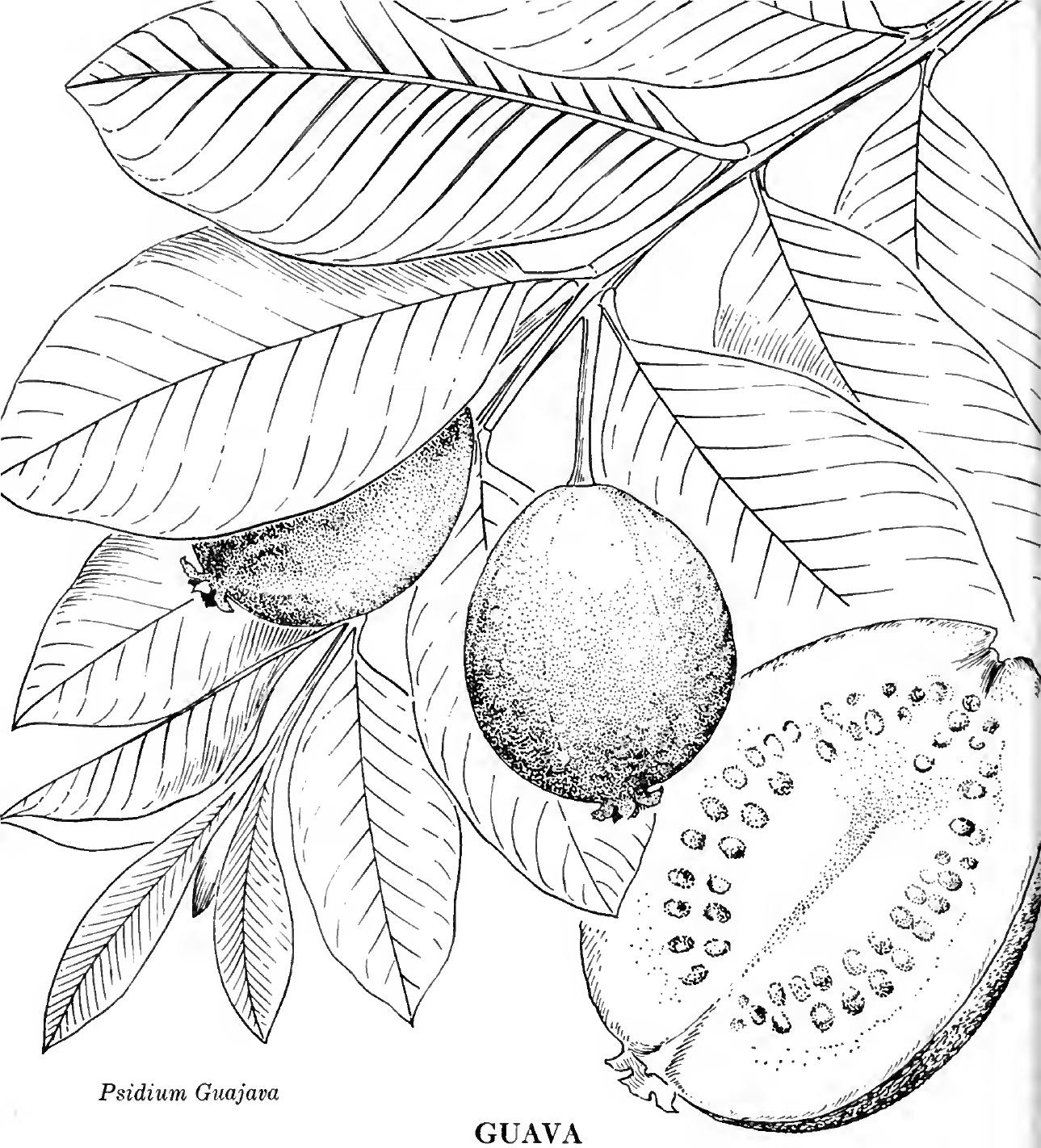

This small fruit tree of Brazil, cultivated and run wild as a shrub in many tropical and subtropical countries, is easily recognized by its smooth and pale flaky bark and regularly alternating pairs of opposite leaves on green, square terminal twigs. The fruits, often hidden by the foliage, are usually roughly egg-shaped and soft when ripe, with thick greenish yellow skin, strongly aromatic flesh, and numerous small seeds. The fruit is eaten fresh by those who do not object to the musky odor, which disappears in cooking. It is commonly made into a preserve, jelly, or paste, a standard dessert in the American tropics. Myrtle family.

Gujave (D.), Goyave (Fr.), Guayaba (Sp.), Goiaba (P.). 


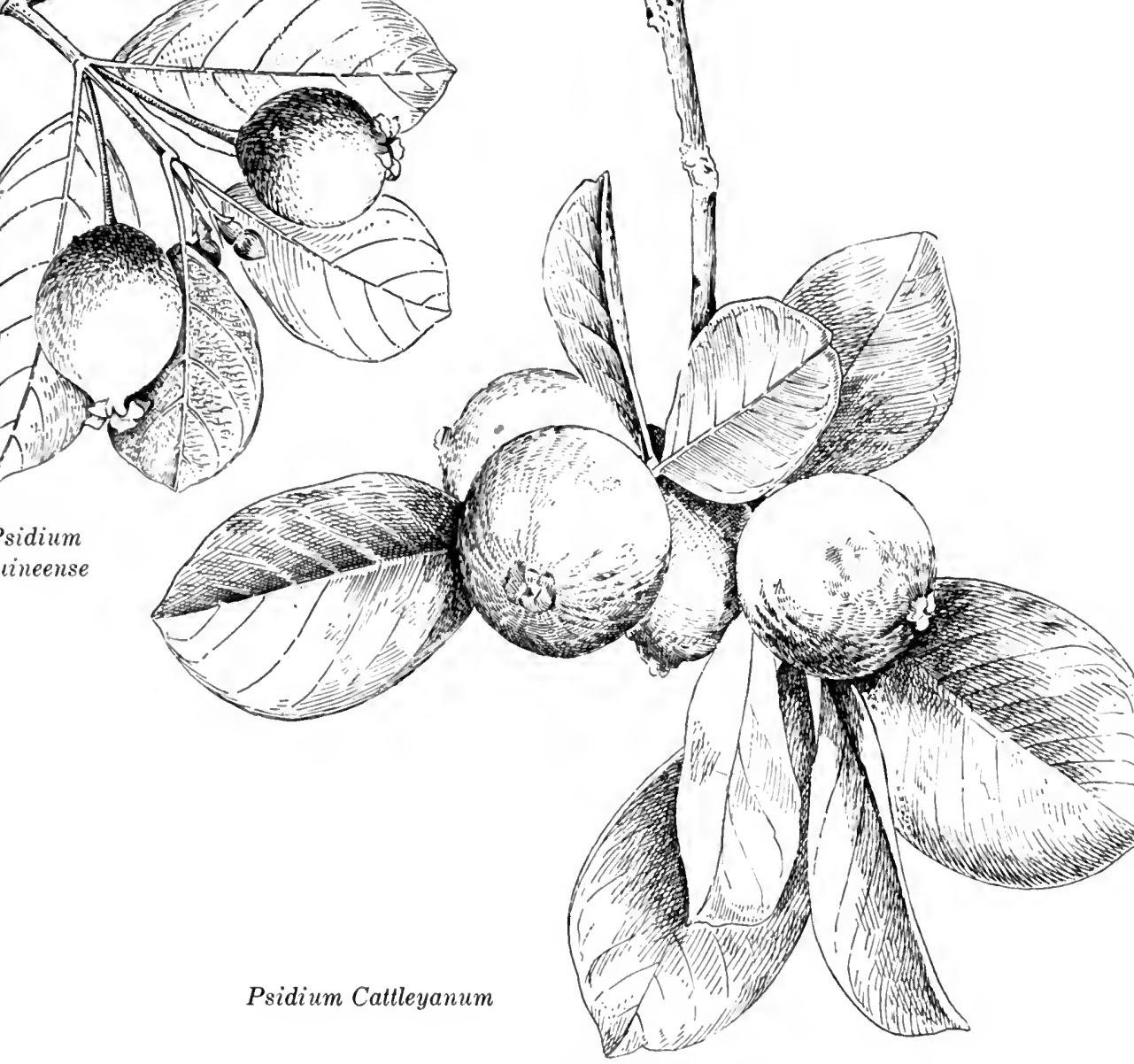

\section{CATTLEY GUAVA}

This smooth and glossy-leaved guava is wild near the coast in Brazil and widely planted there and in many other warm countries. Its smooth globose or pear-shaped fruits are pale yellow to purple when ripe. The pulp may be white but is often decidedly reddish and has a strawberry-like flavor, whence the name Strawberry Guava. The large lemon-colored fruits with white pulp are preferred to those of the ordinary guava.

Strawberry guava (B.W.I.), Goyave fraise (Fr.G.), Guayaba peruana (Venez.), Guayabita fresa (Cuba), Guayaba de China (Mex.), Araçá corôa, Araçá de praia (Braz.).

In poor ground along the coast of northeastern South America there are other wild guavas, some with fruits no larger than a gooseberry. One of the best is that represented to the left above (Psidium guineense), from the savannas of the Guianas and northeastern states of Brazil. Myrtle family.

Wild guava (B.G.), Wilde guave (D.G.), Guayaba sabanera (Venez.), Araçá de campo, Araçahy (Braz.). 




Myrciaria, several species

\section{JABOTICABA}

This distinctly Brazilian fruit is produced by a small tree native and cultivated in the Atlantic tier of states from Rio and São Paulo northward. The small delicate white flowers and the grape-like round fruits, dark red to purplish in color, grow on short stalks from the thin smooth bark of the stem and branches. The fruit, about the size of marbles or larger, seldom over an inch in diameter, is glossy, rather thin-skinned, and surprisingly juicy, with a large round "pit" of one or more seeds. Its agreeable wine-like flavor is irresistible to small boys and a proverbial cause of their stomachaches. Myrtle family. 




Manilkara Zapotilla

(Achras Zapota)

\section{SAPODILLA}

This is one of the very commonest of tropical American fruits, originally from the Yucatan region, where the wild trees are tapped for their white sap which gives chicle for chewing-gum. Cultivated fruits vary greatly in size and shape. They have a grayish or rusty brown slightly rough skin, a very sweet brown granular juicy pulp, and three to six glossy brown seeds radially placed in the pulp. Sapodillas are eaten fresh only. Sapodilla family.

Dilly, Nasberry, Bully tree (B.W.I.), Chico (Guat.), Sapotille (D.G.), Sapotille (F.G.), Níspero (Sp.), Sapotí (Braz.). 




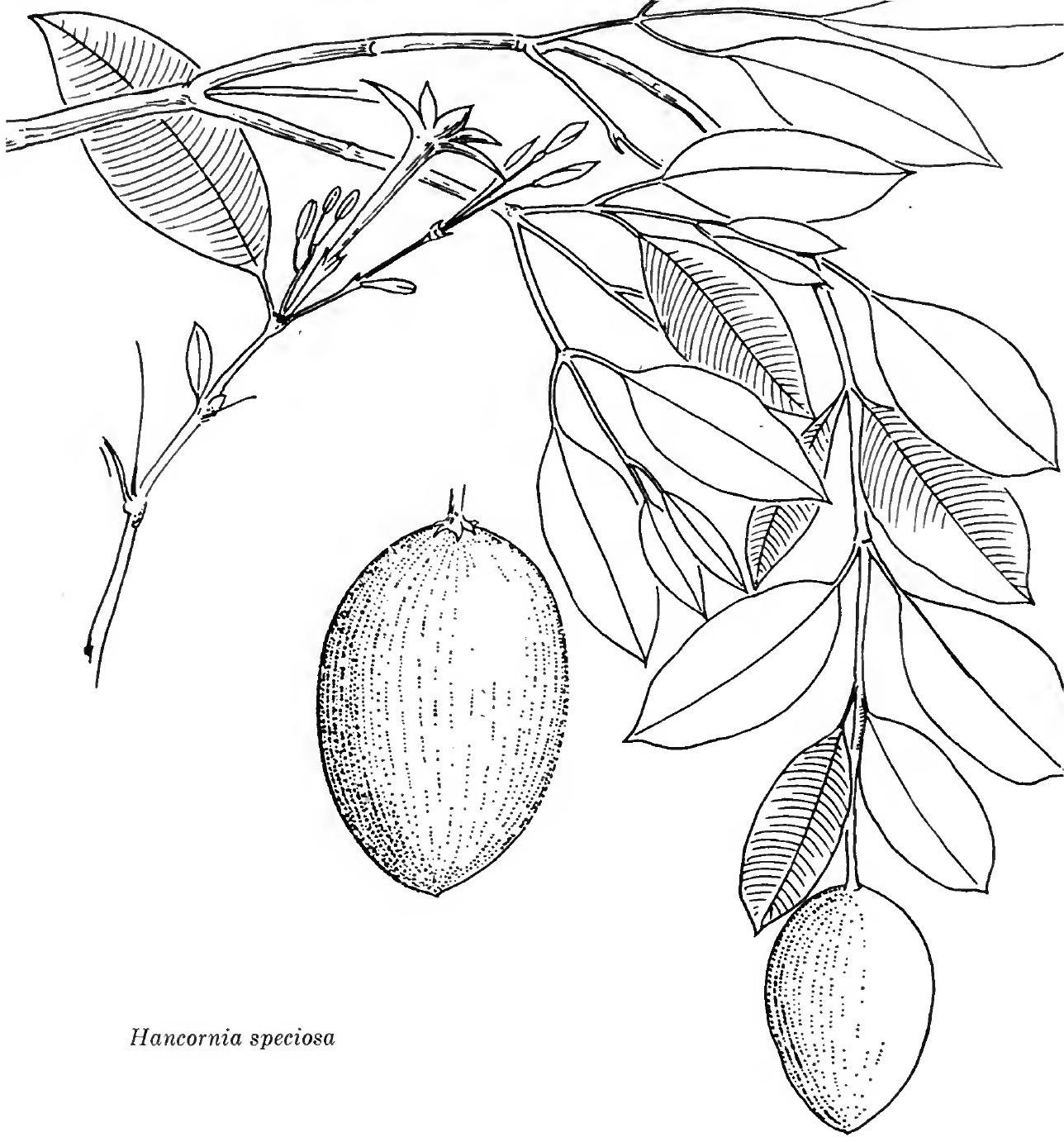

\section{MANGABA}

This is a shrub or small tree with several stems, slender willowy branches, small paired leaves, and jasmin-like flowers. It is remarkable for its sticky latex, which produces rubber of good quality. The fruits are the size of large olives, egg-shaped and smooth, with white flesh and many small seeds. They are spotted or streaked with dark red at maturity, when they fall at a touch. The fruit should be eaten only when perfectly ripe; it is often kept a day after picking, since the immature fruit is considered to be poisonous. This is one of the most delicious and pleasantly scented of wild fruits. Oleander family. 



\section{BIBLIOGRAPHY}

BoIs, D.

Les plantes alimentaires chez tous les peuples et à travers les ages: histoire, utilisation, culture. Vol. 2. Phanérogames fruitièrs. Paris. 1928.

BURKILL, I. H.

A dictionary of the economic products of the Malay Peninsula. 2 vols. London. 1935.

Cook, O. F., and Collins, G. N.

Economic plants of Porto Rico. Contributions of the U.S. National Herbarium, vol. 8, pp. 57-269. Washington. 1903.

Correa, Pio

Diccionario das plantas uteis do Brasil e das exoticas cultivadas. 2 vols. Rio de Janeiro. $1926-31$.

Dahlgren, B. E., and Standley, Paul C.

Edible and poisonous plants of the Caribbean region. Washington.

- Gov't. Printing Office. 1944. Navmed. 127.

\section{DeCandolle, Alphonse}

Origin of cultivated plants. New York. 1885.

\section{Eisen, Gustav}

The fig: its history, culture, and curing. With a descriptive catalogue of the known varieties of figs. Bulletin of the U. S. Department of Agriculture, Division of Pomology, No. 9. Washington. 1901 .

FaWcett, William

Economic plants. An index to economic products of the vegetable kingdom in Jamaica. Kingston. 1891.

\section{Greshoff, M.}

Die nuttige planten van Fransch Guyana in verband met Suriname beschouwd. Buletin van het Kolonial Museum te Harlem. No. 25.

HeYNE, K.

De nuttige planten van Nederlandsch-Indie; tevens synthetische catalogus der versamelingen van het Museum voor Economische Botanie te Buitenzorg. pts. 1-4. Batavia. 1913-17.

\section{LeCointe, Paul}

Arvores e plantas uteis (indigenas e acclimadas). Nomes vernáculos e nomes vulgares, classificação botanica, habitat, principaes applicações e propriedades. A Amazonia Brasileira III. BelemPará. 1934. 
Mowry, HAROLD, and TOY, L. R.

Miscellaneous tropical and sub-tropical Florida fruits. University of Florida, Agricultural Experiment Station Bulletin, No. 223. Gainesville. 1931.

\section{RoIg y MESA, UAN Thomas}

Diccionario Botanico de nombres vulgares cubanos. Estacion Experimental Agrohomica, Santiago de Las Vegas, Boletin No. 54. Habana. 1928.

OCHSE, J. J.

Fruits and fruit culture in the Dutch East Indies. Batavia. 1931.

Pittier, Henri

Ensayo sobre las plantas usuales de Costa Rica. Washington. 1908.

\section{Pittier, Henri}

Manual de las plantas usuales de Venezuela. Caracas. 1926. Supplemento. Caracas. 1939.

Popenoe, Wilson

Manual of the tropical and subtropical fruits, excluding the banana, coconut, pineapple, citrus fruits, olive and fig. New York. 1920.

Solms-Laubach, Hermann, Graf zU

Die Herkunft, Domestication und Verbreitung des gewöhnlichen Feigenbaums (Ficus carica L.). Göttingen. 1882 .

\section{STAHEL, Gerold}

De nuttige planten van Suriname. Department Landbouwproefstation in Suriname, Bulletin No. 57. Paramaribo. 1942.

\section{STURROCK, DAVID}

Tropical fruits for southern Florida and Cuba and their uses. Publications of the Atkins Institution of the Arnold Arboretum of Harvard Univ. Jamaica Plain, Mass. 1940.

\section{SWINGLE, WALTER T.}

The date palm and its utilization in the southwestern states. U. S. Department of Agriculture, Bureau of Plant Industry, Bulletin No. 53. Washington. 1904.

The present status of date culture in the southwestern states. U. S. Department of Agriculture, Bureau of Plant Industry, Circular No. 129-A. Washington. 1913.

The botany of Citrus and its wild relatives of the orange subfamily. In Webber and Batchelor. 1943.

\section{United States Department of Agriculture,} Bureau of Plant Industry

Inventory of foreign seeds and plants imported by the Office of Foreign Seed and Plant Introduction. Nos.1-113. Washington. 1898-1934. (Nos. 1-8 were issued by the Division of Botany; Nos. 9-30 were issued as Bulletins of the Bureau of Plant Industry.) 
Webber, HeRbert J., and Batchelor, LeON D.

The citrus industry. Vol. 1. History, botany, and breeding. Berkeley. 1943.

Williams, R. O. and R. O., JR.

The useful and ornamental plants of Trinidad and Tobago. Revised 3rd ed. Trinidad \& Tobago. 1941.

United Fruit Company, Educational Department

About Bananas, pp. 21. Boston. 1931. 


\section{INDEX}

PAGE

Achras Zapota..........6 62

Akee. ............ 15

Anacardium occidentale.... . 47

Ananas comosus.......... 31 sativus............ 31

Annona Cherimola......... 38

muricata. ............44 40

reticulata............ 37

squamosa........... 39

Artocarpus altilis........ 6

communis . ........... 6

heterophylla......... 7

incisa.............. 6

integrifolia.......... 7

Assai ............... 34

Averrhoa Bilimbi......... 10

Carambola............. 11

Avocado............. 32

Bacurí............... 53

Bananas. .................... 1

Barbados cherry . . . . . . . 46

“ gooseberry....... 57

Bell-apple........... 55

Bilimbi............... 10

Biribá.............41

Blighia sapida.......... 15

Breadfruit.............. 6

Calocarpum mammosum.... 65

Sapota.............65 65

Carambola ............ 11

Carica Papaya........... 33

Carissa grandiflora........ 28

Caryocar spp...........51

Cashew ..............47

Casimiroa edulis ..........45

Cattley guava.......... 59

Cereus spp............. 56

Ceriman ................. 36

Cherimoya............ 38

Chrysobalanus Icaco . . . . . 42

Chrysophyllum Cainito . . . . . 64

Cicca disticha............ 13

Citron.............. 2

Citrus fruits.......... 2

Coco-plum. . . . . . . . . . 42

Cupu-assú ............... 50

Curaçao-apple.......... 25

Custard-apple.......... 37
PAGE

Dates............... 3

Dillenia indica........... 20

Diospyros Kaki. . . . . . . . . 27

Durian............... 19

Durio zibethinus. . . . . . . . 19

Eriobotrya japonica....... 8

Etrog.............. 2

Eugenia aquea........... 25

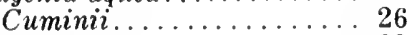

Jambos . . . . . . . . . . 23

javanica............. 25

malaccensis........... 24

uniflora............ 60

Euterpe oleracea........... 34

Ficus Carica............. 5

Figs............... 5

Garcinia Mangostana...... 21

Genip..............49

Genipa americana........6 67

Genipap............667

Golden-apple . . . . . . . . . 14

Gooseberry, Otaheite....... 13

Granadilla, giant. . . . . . . 54 purple............ 55

sweet............... . 55

Grapefruit............. 2

Guava, common........ 58

Cattley............ 59

strawberry. . . . . . . . 59

wild . . . . . . . . . . . 59

Guilielma Gasipaës . . . . . . . 35

Hancornia speciosa . . . . . . 66

Hog-plum ............ 14

Hondapara. . . . . . . . 20

Icaco-plum . . . . . . . . . . 42

Inga.............. 44

Inga ingoides. . . . . . . 44

nobilis . . . . . . . . . . 44

Jaboticaba . . . . . . . . . 61

Jackfruit. . . . . . . . . . . 7

Java-plum............ 26

Jujube............... 18

Kumquats........... 2

Langsat. . . . . . . . . . . . 12

Lansium domesticum . . . . . . 12 


\section{INDEX}

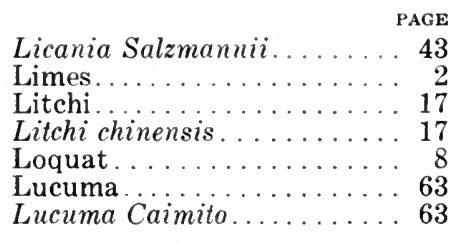

Malay-apple............ 24

Malpighia punicifolia var. emarginata........... 46

Mamey sapote.........65

Mammea americana....... 52

Mammee............. 52

Mangaba...........6 66

Mangifera indica......... 4

Mango............... 4

Mangosteen ...........21

Manilkara Zapotilla.......62

Melicocca bijuga......... 49

Mombin, red ........... 48 yellow.............. 14

Monstera deliciosa . . . . . . 36

Musa paradisiaca......... 1 subsp. sapientium....... 1

Myrciaria $\mathrm{spp} . \ldots \ldots \ldots \ldots 61$

Natal plum............. 28

Nephelium lappaceum...... 16

Oití 43

Opuntia Tuna .......... 56

Oranges............... 2

Otaheite Gooseberry....... 13

Papaya.............. 33

Passiflora edulis......... 55

ligularis.............. 55

quadrangularis........ 54

Peach palm............ 35

Pereskia aculeata........ 57

Persea americana......... 32

Persimmon, Japanese. . . . . 27

Pineapple............. 31

Phoenix dactylifera........ 3

Phyllanthus distichus........ 13

Plantain............. 1

Platonia insignis........ 53
PAGE

Pomegranate.........2.2

Prickly pear .......... 56

Pouteria Caimito......... 63

Psidium Cattleyanum...... 59 Guajava............. 58 guineense........... 59

Pummelo............. 2

Punica granatum........... 22

Rambutan............. 16

Red Mombin........... 48

Rheedia sp............ 53

Rollinia pulchrinervia...... 41

Rose-apple............... 23

Rose-apple, Water........ 25

Sapodilla............. 62

Sapote................. . 65

white............ 45

Satsuma orange........ 2

Shaddock............. 2

Souari nuts............ 51

Soursop............. 40

Spondias dulcis............ 14

lutea............... 14

purpurea............48

Star-apple............ 64

Sugar-apple............ . 39

Surinam cherry . . . . . . . 60

Sweetsop . . . . . . . . . . . 39

Syzygium aquea......... 25 Cuminii............26

Jambos . . . . . . . . . . . 23

javanica............. 25

malaccensis. . . . . . . . . 24

Tamarind ............. 9

Tamarindus indica........ 9

Theobroma grandiflorum.... 50

Tuna................ 56

Water-lemon............ 55

Water Rose-apple......... 25

White Sapote... . . . . . . 45

Yellow mombin.......... 14

Zizyphus Jujuba. . . . . . . 18 



\section{$\bullet$}


